\title{
Palm Oil Mill Effluent Treatment Processes-A Review
}

\author{
Sharifah Mohammad ${ }^{1}\left(\mathbb{D}\right.$, Siti Baidurah ${ }^{1, *} \mathbb{0}$, Takaomi Kobayashi ${ }^{2}$, Norli Ismail ${ }^{1}$ and Cheu Peng Leh ${ }^{1}$ \\ 1 School of Industrial Technology, Universiti Sains Malaysia, Minden 11800, Penang, Malaysia; \\ msharifah@student.usm.my (S.M.); norlii@usm.my (N.I.); cpleh@usm.my (C.P.L.) \\ 2 Department of Science of Technology Innovation, Nagaoka University of Technology, 1603-1 Kami-tomioka, \\ Nagaoka 940-2188, Niigata, Japan; takaomi@vos.nagaokaut.ac.jp \\ * Correspondence: sitibaidurah@usm.my; Tel.: +60-4-6536381
}

Citation: Mohammad, S.; Baidurah, S.; Kobayashi, T.; Ismail, N.; Leh, C.P. Palm Oil Mill Effluent Treatment Processes-A Review. Processes 2021, 9, 739. https://doi.org/10.3390/ pr9050739

Academic Editor: Wei Wang

Received: 1 April 2021

Accepted: 19 April 2021

Published: 22 April 2021

Publisher's Note: MDPI stays neutral with regard to jurisdictional claims in published maps and institutional affiliations.

Copyright: (c) 2021 by the authors. Licensee MDPI, Basel, Switzerland. This article is an open access article distributed under the terms and conditions of the Creative Commons Attribution (CC BY) license (https:/ / creativecommons.org/licenses/by/ $4.0 /)$.

\begin{abstract}
Ponding system or land application techniques are widely used at industrial scale to treat palm oil mill effluent (POME) prior to discharge to the environment. POME is considered as one of the major problems that has generated voluminously from the palm oil industries. The main purpose of this article is to organize the scattered available information on various aspects and a wide range of promising current POME treatments including biological microorganisms, physicochemical methods of coagulation, and membrane and thermochemical process. In addition, the integrated system of anaerobic-aerobic bioreactor (IAAB), which has been touted as highly efficient with easy control at acceptable temperature range and shorter treatment time, has potential to be exploited for POME treatment. The main influencing factors for IAAB POME treatment are highlighted as outstanding characteristics for challenges and future prospects.
\end{abstract}

Keywords: palm oil mill effluent; ponding system; biological treatment; physicochemical treatment; membrane treatment; thermochemical treatment

\section{Introduction}

Now, palm oil is recognized as high-quality oil used popularly and primarily for cooking in developing countries. Thus, oil palm tree plantations are spreading across Asia, Africa, and Latin America. From the viewpoint of soil and water pollution, palm oil production provides serious problems. Palm oil mill effluent (POME) exists in forms of high solid, oil, and grease and includes biochemical oxygen demand (BOD) and chemical oxygen demand (COD) in richness. These are major concerns in environmental pollutant due to their adverse effects to many forms of life [1]. The direct discharge of POME in the environment is a matter of concern for both toxicological and esthetical reasons. The majority of the palm oil mills use the addition of water during the extraction process of crude palm oil (CPO) from the fresh fruit bunch (FFB). As a result, a considerable amount of wastewater was generated [2] and stored in ponds. In major oil palm-producing nations such as Indonesia and Malaysia, the production of CPO has resulted in an annual production of up to 3 billion pounds of POME. Furthermore, it is estimated that $5-7.5$ tonnes of water are required to produce 1 tonne of $\mathrm{CPO}$, with more than $50 \%$ of the water ending up as POME [3,4].

POME exists as viscous and brownish liquid containing approximately more than $95-96 \%$ of water, together with $0.6-0.7 \%$ of oils and $2-4 \%$ of suspended solids for the source of fruit debris, and is known as a non-toxic substance [5]. The brownish colour is due to the origins of carotene $(8 \mathrm{mg} / \mathrm{L})$, pectin $(3400 \mathrm{mg} / \mathrm{L})$, tannin, phenolic $(5800 \mathrm{mg} / \mathrm{L})$, and lignin $(4700 \mathrm{mg} / \mathrm{L})$, thus making it a nutrient-rich substance [5]. POME is known to be a major problem in every oil palm factory due to its voluminous abundance and disposal problems. The direct discharge of POME on the land results in clogging, water logging of the soil, and kills the vegetation on contact. Discharge of the effluent into waterway causes water depletion, resulting in aquatic pollution [6]. In extreme cases, river water consequently turns brown with an unpleasant smell and viscous characteristic. Mortality of fish and 
other aquatic organism increases, and local people are deprived of the local water sources for domestic uses and fishing. Therefore, the effective techniques for POME treatment are of the uttermost significance.

During the past two decades, several biological, physical, and chemical techniques have been reported as treatment methods; few, however, have been accepted by the industries [7]. Amongst the numerous and latest alternative treatment techniques are integrated systems of anaerobic-aerobic bioreactor (IAAB). The procedure of choice gives the best results in POME treatment as IAAB can reduce COD and BOD within 115 days [8]. Recently, numerous approaches have been studied for the development of cheaper and effective treatment techniques. Many non-conventional low-cost methods including utilization of microorganisms were proposed as techniques of POME treatments [9-19].

The present article deals with the technical feasibility of various non-conventional and highly effective treatments for POME. The main aim of this review is to provide a summary of recent topics concerning the optimum treatment output with low COD, BOD, total suspended solid (TSS), and colour with short treatment time. Science Direct were searched (final search February 2021) using a combination of search terminology of palm oil effluent, treatment, and fermentation. Among all mooted POME treatment processes, only a final selection of 124 papers fostering the most effective treatment processes was identified and included as references.

\section{Palm Oil Production Process and Oil Trapping Pond System}

The majority of the oil palm mill employed a wet process for the oil extraction, utilizing fresh fruit bunch (FFB). No chemicals are added during the oil extraction process from the oil palm fruits, thereby making all wastes generated as non-toxic to the environment. By using United Oil Palm (UOP) Industries Sdn. Bhd., Malaysia as a reference point, the treatment process starting from the FFB and the extent of the properties changes occurring after decomposition at each individual pond until final discharge was presented in Figure 1.

For grading, initially, FFB is retrieved from the farm and transported to the mills prior to processing. As categorized accordingly based on their weight and quality, the grading step is crucial to ensure only good quality of FFB selected and can eliminate the deteriorated FFB. The utilization of damaged palm fruits will render low-quality palm oil. The selected good quality FFB were dropped onto a ramp and transferred into horizontal sterilizer cages.

The sterilizer cages with the FFB were exposed to high-temperature pressurized steam under $40 \mathrm{psi}$ for $75-90 \mathrm{~min}$ at $140{ }^{\circ} \mathrm{C}$. There are four objectives of the FFB sterilization: (1) most importantly, to deactivate the enzymes responsible for the formation of free fatty acids; (2) to remove external impurities; (3) to soften and loosen the fruitlets from bunches; and (4) to detach the kernels from the shells prior stripping process. The sterilization process acts as the main contributor to the POME accumulation in the form of sterilizer condensate. Also, the sterilized fruit bunches were fed and lifted into a rotating drum. In the drum stripper, the fruitlets were detached and separated from the bunches. At this stage, the loose fruitlets were softened and digested under steam-heated conditions by a steam jacket or by direct live steam injection. Simultaneously, the high pressure and high temperature broke the oil-bearing cells of the mesocarp and were channelled to a mechanical twin screw-press machine for crude palm oil (CPO) extraction $[20,21]$ following clarification.

It was known that the digested CPO consisted of $35-45 \%$ palm oil, $45-55 \%$ water, and residual fibrous materials and was pumped into a clarification tank in order to separate the oil from $\mathrm{CPO}$ at $90^{\circ} \mathrm{C}$ in order to further enrich the oil separation process. Then, the oil was skimmed-off from the top of the tank. The bottom phase of the clarification tank still contained remaining residual oil and again passed through the sludge separator, namely decanter heavy phase (DHP) tank and de-oiling tank. The sludge is the by-product of the clarification, and the purification process is the second source of POME in terms of its polluting strength and quantity. The recovered oil was returned to the clarification tank. 


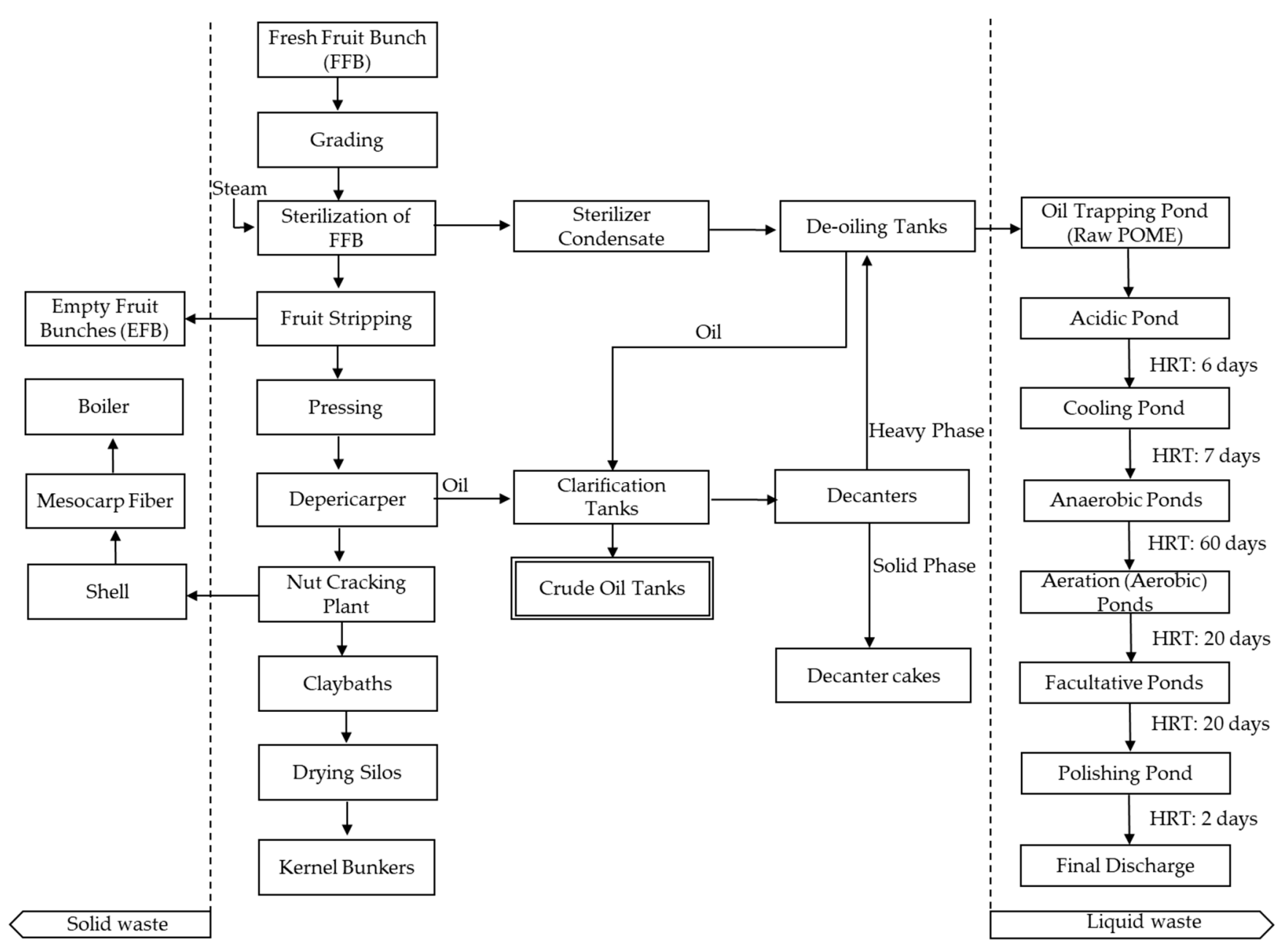

Figure 1. Palm oil production process and oil trapping pond for POME treatment in Malaysia.

In the depericarping, the nuts were removed by the digestion and pressing processes for depericarp and then the residual fibres transported to the nut cracking machine or plant. The cracked mixture of kernels and shells was then separated in a hydrocyclone and claybaths. The third source of POME was fed from the wash-water of the hydrocyclone. The kernel produced was then stored into kernel bunkers before being transferred to the mill for oil extraction. Shell wastes were piled with the mesocarp fibers in the boiler for power generation. The remaining wastewater was discharged accordingly to their subsequent treatment process. Overall, the production of $\mathrm{CPO}$ will generate a by-product of solid wastes such as mesocarp fibres and EFB. These solid wastes still can be utilized for other purposes. Raw POME is an example of liquid waste and is subjected to various stages of pond treatments. Detailed elaboration associated with POME treatment will be discussed in the next sub-topic. In contrast, the de-oiling tank feeds POME waste oil to the trapping pound. The ponding system involved several series of ponds of acidic, cooling, anaerobic, aeration (aerobic), facultative and final polishing ponds.

\section{Characteristics of Palm Oil Mill Effluent (POME)}

Typically, in the process of oil palm, POME is accumulated from three different sources such as clarification wastewater, sterilizer condensate, and hydro-cyclone wastewater [22]. The general characteristics of each raw POME are presented in Table 1. 
Table 1. General characteristics of raw POME.

\begin{tabular}{lll}
\hline Parameters & Concentration Range & Current Discharge Limit \\
\hline Chemical oxygen demand (COD) & $15,000-100,000$ & - \\
Biochemical oxygen demand (BOD) & $10,250-43,750$ & 100 \\
Total suspended solids (TSS) & $5000-54,000$ & 400 \\
Oil and grease & $130-18,000$ & 50 \\
Temperature & $80-90$ & 45 \\
pH & $3.4-5.2$ & $5-9$ \\
\hline
\end{tabular}

All values, except $\mathrm{pH}$ and temperature, were expressed in $\mathrm{mg} / \mathrm{L}$.

The raw POME is a thick brownish colour in the viscous and colloidal suspension, which contains high water contents (95-96\%), suspended solids (2-4\%), and oils $(0.6-0.7 \%)$. POME exists as an acidic substance with unpleasant odour, high value of COD, and BOD, which can be concomitantly sensitive to environmental issues [23,24]. Many researchers reported on the POME nutritional composition, as well as the minerals, trace elements, and heavy metals $[23,25]$. The XRF analysis of POME, sampled in Penang, Malaysia, was obtained below; C 51.0\%, O 35.3\%, Na 0.0632\%, Mg 1.09\%, Al 0.215\%, Si 0.552\% P 0.429\%, $\mathrm{S} 0.553 \%, \mathrm{Cl} 2.75 \%, \mathrm{~K} 6.77 \%$, Ca $1.09 \%$, Mn $0.0243 \%$, Fe $0.141 \%$, and $\mathrm{Rb} 0.0286 \%$. The quality of the effluent produced was affected by many factors including maturation degree of FFB, different treatment systems, as well as varied batches of FFB and factories system [26]. Hence, in order to control and minimize the pollution impact towards the environment, the Department of Environment (DOE), Malaysia, had enacted Environmental Quality Act (EQA) 1974 and set standard limits for the discharge of POME into the environment [27].

\section{POME Treatment Process}

\subsection{Ponding System or Land Application}

Ponding system or land application is the most widely used at the majority of palm oil mills (85\%) for effluent treatment, due to cost-effectiveness, low maintenance costs, energy efficiency, system reliability, and simple design [28]. However, this obsolete ponding system is often necessary for long hydraulic retention time (HRT) and large pond area. This is considered to be inefficient in certain ways [29].

The configuration of POME treatment via a pond system is also known as waste stabilization ponds of acidic to final polishing ponds contain an overall HRT of 100-120 days prior to discharge to the environment. The raw POME in the oil-trapping pond was pumped into the acidification pond and retained for about 6 days. Then, the POME was pumped into a cooling pond through a cooling tower and retained for another 7 days. Cooling pond reduced the POME temperature to be $35-38{ }^{\circ} \mathrm{C}$ and stabilised the $\mathrm{pH}$ prior to the anaerobic stage. While cooling, high initial temperature of POME promotes thermal and anaerobic digestion, mainly via hydrolysis and acidogenesis. Anaerobic treatment ponds were noticed as the most effective method to treat high-strength wastewater by anaerobic decomposition.

The hydrolysis process involved the breakdown of complex polymers such as carbohydrates, proteins, and lipid into respective monomers. For example, sugar, amino acids, and fatty acids were facilitated by the thermo-tolerant microbes. In the acidogenesis process, carbon-containing monomers are fermented into volatile fatty acids (VFA), such as acetic acid $(\mathrm{HAc})$, propionic acid $(\mathrm{HPr})$, butyric acid $(\mathrm{HBu})$, valeric acid $(\mathrm{HVa})$ with trace-non VFA, and lactic acid [23]. Acetogenesis reduced the long chain VFA ( $\mathrm{HPr}, \mathrm{HBu}$ and $\mathrm{HVa}$ ) from the acidogenesis into hydrogen and carbon dioxide $\left(\mathrm{CO}_{2}\right)$. Hydrogen and $\mathrm{CO}_{2}$ were then consumed by hydrogenotropic methanogens, while $\mathrm{HAc}$ and $\mathrm{CO}_{2}$ were utilized by acetoclastic methanogens that produced methane gas. The methane gas is considered as the final value-added product for the biogas production. Following degradation of the long chain fatty acids (LCFA) and VFA, anaerobically treated POME became alkaline and existed as blackish brown due to partial degradation of the lignin into the phenolic [24]. Anaerobic treatment stages comprised of four ponding series with total HRT of 54-60 days. 
Then, anaerobic POME is further treated using a three series of aeration ponds with the floating aerators for about 20 days before being discharged into the facultative ponds.

Facultative ponds consisted of three ponding series, which are very crucial to furthermore reduce the organic content in the effluent, prior to discharging to the waterway, as complied with the Environmental Quality Act (EQA) 1974, the stipulated regulation for crude palm oil treated effluent discharge. Through sedimentation requiring approximately 2 days, final polishing pond clarifies suspended microbes from the aerobically-treated POME. This ponding system has been described by many researchers [30,31] successes for effluent treatment and complies with the disposal standard requirement with some limitation to the minimum disposal standard requirement [32].

The anaerobic ponding system was found to demonstrate great performance in treating POME due to reduction of high-level organic properties in POME [33]. However, 100\% decolourization was unable to be achieved using this treatment system [34]. Open ponding system successfully reduced the levels of COD (100-1725 mg/L), BOD (100-610 mg/L) and ammoniacal nitrogen (100-200 $\mathrm{mg} / \mathrm{L}$ ) to a certain range. Nevertheless, the open ponding system requires extensive land area, concomitantly leading to serious environmental problems by the production of methane gas, resulting in ozone layer depletion [35]. Furthermore, the open and closed digesting tanks were commonly exploited after the ponding system, due to its availability on a wide range of volumetric capacity. Although these types of tanks had low capital and operating costs, with shorter HRT (20-25 days) and limited land area requirement [36], they still had a significant amount of harmful biogas (approximately $5.5 \mathrm{~kg}$ of $\mathrm{CH}_{4}$ per tonne), which was produced due to the lack of a gas retrieval device in the system [37]. Even though the implementation of $\mathrm{CH}_{4}$ capturing system provides various advantages such as reducing the greenhouse gaseous emission, generating renewable energy, and improving soil quality and FFB production, the system is too costly for the next stage in commercialisation [38].

\subsection{Biological Treatment}

Although ponding system is popular for POME treatment technique at the industrial scale, large land area (30-45 acres) and long HRT (100-160 days) entail an economical drawback. Thus, there is a need for the development of low-cost and utilization of available materials, which can be used more economically at the industrial scale. Due to the aforementioned problems, research interest has increased regarding the alternative production technique to partially replace the obsolete open ponding system. Especially for POME treatment by biological techniques in the presence of bacteria, fungi, yeast, microalgae, and other microbial cultures, which have been the subjects of many recent researcher. Table 2 summarizes various biological processes for POME treatments. In contrast to the ponding system or land application, the anaerobic system would be more preferable, due to higher organic conversion efficiency of COD, BOD, TSS, and colour, followed by oil and grease [8]. Nowadays, the anaerobic system is claimed to be unique and beneficial for environmentally and friendly stabilized systems and has the ability to produce an energy source in the form of the methane gas, $\mathrm{CH}_{4}[8,20,31]$. Emerging from the current anaerobic treatment, some modifications on the anaerobic treatment system have been developed for the POME wastewater by aerobic suspended growth processes, attached growth anaerobic process with immobilised cell bioreactors, anaerobic fluidised bed reactors and anaerobic filters, anaerobic sludge blanket processes using both up-flow anaerobic sludge blanket reactor and anaerobic baffled bioreactor, membrane separation anaerobic treatment process, and integrated anaerobic treatment processes [14,31]. Chan et al. [39] concluded that the organic matter in an anaerobic effluent is not fully stabilized and additional post treatment was necessary in order to remove some ions' presence in the effluent. Hence, in order to meet the discharge standard, the anaerobic system was coupled with aerobic degradation of the POME.

Referring to Table 2, the highest COD removal (99.60\%) was obtained by utilizing the integrated system of the anaerobic-aerobic batch (IAAB) reactors [8]. IAAB enabled to 
operate at organic loading rate (OLR) of $7-12 \mathrm{~kg} C O D / \mathrm{m}^{3}$ day with a continuous mixing flowrate of $140 \mathrm{~m}^{3} / \mathrm{h}$. A significant amount of $\mathrm{CH}_{4}$ gas (45-68\%) was produced during the treatment. So this revealed high potential POME treatment to efficiently utilize the main substrate for the microbial growth and biogas production [8]. The system was capable of reducing the treatment time to less than 115 days, as compared with the current pond treatment system. In another study, the thermophilically mixed culture was able to reduce up to $90.00 \%$ of the COD in the POME within only 6 days for working volume of $2.5 \mathrm{~L}$ by batch continuous stirred tank reactor [40]. Until now, there have been insufficient scientific reports associated with the utilization of the aerobic post-treatment anaerobically digested POME. However, sequencing batch reactors (SBR) or activated sludge reactors (ASR) were reported to be utilized as post treatment for anaerobic processes. Better performance was achieved at optimum OLR of $1.8-4.2 \mathrm{~kg}$ COD $/ \mathrm{m}^{3}$ day utilizing SBR on the COD $(96.00 \%)$, BOD $(99.00 \%)$ and TSS (99.00\%) removal efficiency within $22 \mathrm{~h}$ [2], simultaneously leading the discharge limits. The controlled dissolved oxygen and $\mathrm{pH}$ were controlled throughout the fermentation, thus demonstrating positive results of using the SBR system. Apart from the anaerobic and aerobic digestion, an integrated system of biological and membrane separation treatment was identified as an ultra-sonic membrane assisted system (UMAS) with maximum COD removal efficiency $(98.90 \%)$ within 7 days for $200 \mathrm{~L}$ volume of raw POME [41]. The aerobic treatment under mesophilic condition varied accordingly with efficient removal of the COD, BOD, and TSS, depending on the different temperatures during the process [14,42].

Phytoremediation is another green technology that has received huge interest over the past decades [15]. The application of phytoremediation in the wastewater treatment offers various advantages in terms of cost-effective alternatives, aesthetic appearances, and sustainability concern. The key element is plant selection prior to proceeding with the implementation of remediation techniques. The suitable properties were high nutrients uptake, as well as heavy metals uptake in the wastewater [43]. Phytoremediation of POME using Typha latifolia was effective in reducing the COD concentration up to $97.18 \%$ [44]. The utilization of Vetiveria zizanioides was reported to reduce the COD and BOD concentration effectively up to $94 \%$ and $90 \%$ within 14 days for $45 \mathrm{~L}$ POME volume [15]. Water spinach (Ipomoea aquatic Forsk) was another promising agent for successful reduction of the COD and colour of POME at $86.3 \%$ and $95.3 \%$, respectively [45]. This was conducted for 15 days with better achievement in decolourising 75\% (7.5 L POME + 2.5 L tap water, respectively) [45]. Furthermore, Baihaqi et al. [46] reported the use of Spirogyra sp. to reduce the COD concentration to $63.6 \%$ within 20 days for $75 \mathrm{~mL} \cdot \mathrm{L}^{-1}$ of POME. Interestingly, the majority of the phytoremediation techniques had high potential to reduce the nitrate and phosphate content, as well as the wastewater contaminants including chromium [47], lead [48], and textile dyes [49] in highly polluted media, which have been reported on by Chanu and Gupta [48]. Phytoremediation is easy to handle, cost effective, readily available, and environment friendly [50].

In addition to the aquatic plants such as Pistia stratoites [51] and Eichorniacrassipes [52], there were a few attempts in cultivating microalgae in the POME such as Chlorella spp. UKM 8 and Chlamydomonas sp. UKM 6 in reducing the COD concentration up to $92 \%$ within 21 days for $2 \mathrm{~L}$ of POME under different inoculum sizes that ranged from 5-15\% v/v [53]. Hariz et al. [54] utilized two stages of treatment for about 25 days by utilizing Scenedesmus sp. UKM9 and Chlorella sp. UKM2 in treating POME, resulting in 71\% reduction of COD, $86 \%$ reduction of total nitrogen, and $85 \%$ reduction of phosphate with 25 days of treatment for $85 \% v / v$ of POME. Overall performance of phytoremediation techniques was evaluated for about 14-25 days of treatment period with varied results.

Due to high content of organic and mineral constituents in POME, these properties were an advantage of convenient fermentation processes as a feasible treatment method. POME accumulated lipid, bioplastics synthesis, citric acid, and bioethanol production by various microorganisms $[16,55-57]$. The $50 \%(v / v)$ POME was found to generate the highest biomass growth $(8.09 \mathrm{~g} / \mathrm{L})$ and lipid accumulation $(1.46 \mathrm{~g} / \mathrm{L})$, with lipid content 
of $18.04 \%$ on dry weight basis utilising Bacillus cereus via batch fermentation system [16]. The substantial reduction in pollution load specifically in COD and BOD for 50\% $(v / v)$ POME demonstrating removal efficiencies of $79.35 \%$ and $72.65 \%$ within 6 days. The B. cereus cultivation in POME could be a promising method for attaining higher biomass growth and lipid production in parallel with the bioremediation concept [16]. By a doublestep process [55], the breakdown of POME involved acetic acid and propionic acid, thus continuing with the polyhydroxyalkanoates (PHA) synthesis by Rhodobacter sphaeroides. Furthermore, the usage of POME hydrolysated a substrate in producing citric acid under controlled parameters and then effectively reduced the COD level more than $80 \%$ and saved the treatment costs, simultaneously minimising the current environmental problems [56]. Spontaneous fermentation of bioethanol utilising POME was performed by Wakil et al. [57] for both, with amendments of glucose, corn steep liquor, and sugarcane bagasse, and without amendments. The highest ethanol content was obtained at $18.17 \mathrm{~g} / \mathrm{L}(2.3 \%)$ with the amendment, whereas $3.95 \mathrm{~g} / \mathrm{L}$ ethanol $(0.5 \%)$ was achieved without the amendments. In the POME fermentation, the optimum condition was of $30 \mathrm{~g} / \mathrm{L}$ glucose and $30 \mathrm{~g} / \mathrm{L}$ sugarcane bagasse at $\mathrm{pH} 8.5$ for 12 days, although there were no reported values on the COD, BOD, and TSS throughout the fermentation. To date, the organic content in POME can be completely converted into useful bioethanol, but the process yet requires complicated handling procedures and time-consuming processes in the industrial scale of the optimizing fermentation condition.

Microbial fuel cell (MFC) has gained attention by many researchers in treating POME. In contrast to the obsolete ponding system, MFC was performed at only room temperature with low substrate concentration levels. With the aid of microorganisms, an organic-rich wastewater was used to generate electrical energy, which is considered as cost-effective and sustainable energy source. Even though POME can be transformed into an electricity source utilizing a single chamber of MFC, still the COD and BOD removal efficiencies remains without satisfaction. The observation of low COD and BOD removal was due to the substrate type, treatment parameters, reactor design, and operational costs [58]. Barani Tharan et al. [59] treated both raw POME and diluted POME in a dual chamber of MFC by using polyacrylonitrile carbon felt and a Nafion 117 membrane. The lower COD removal efficiency $(45.00 \%)$ was obtained in the raw POME, as compared to the diluted POME $(70 \%)$ after 15 days of the incubation period. However, the power electricity generation increased with the increment of initial COD value, implying that the MFC system with raw POME performed better than the diluted one. A combination of two-staged MFCs coupled with the immobilised biological aerated filter was conducted in replacing the conventional method of anaerobic biological treatment system. This was an advanced system for successful reduction of the COD up to $96.50 \%$ within 10 days operation in 2.36 L of working volume [60]. Although MFC is an easy handling and simple system, some of the limitations including the capital costs and the technical parts of the electron transfer performances still remain as major drawbacks. 
Table 2. Summary of various biological treatment techniques for POME.

\begin{tabular}{|c|c|c|c|c|c|c|c|c|c|c|c|c|}
\hline \multirow[b]{2}{*}{ No. } & \multirow[b]{2}{*}{$\begin{array}{c}\text { Microbes or } \\
\text { Biological Seeding }\end{array}$} & \multicolumn{6}{|c|}{ Concentration, mg/L or Removal Efficiency, $\%$} & \multirow[b]{2}{*}{$\begin{array}{c}\mathrm{CH}_{4} \\
\text { Release(\%) }\end{array}$} & \multicolumn{3}{|c|}{ Process Aspects } & \multirow[b]{2}{*}{ Ref. } \\
\hline & & $\begin{array}{l}\mathrm{COD} \\
(\mathrm{mg} / \mathrm{L})\end{array}$ & $\begin{array}{c}\text { BOD } \\
(\mathrm{mg} / \mathrm{L})\end{array}$ & $\begin{array}{c}\text { TSS } \\
(\mathrm{mg} / \mathrm{L})\end{array}$ & $\begin{array}{l}\text { Colour } \\
(\mathrm{mg} / \mathrm{L})\end{array}$ & $\begin{array}{c}\text { Oil } \\
(\mathrm{mg} / \mathrm{L})\end{array}$ & $\begin{array}{c}\mathrm{CO}_{2} \\
\text { Fixation } \\
\text { (g CO } / \text { L/day) }\end{array}$ & & $\begin{array}{l}\text { Working } \\
\text { Volume } \\
\text { (L) }\end{array}$ & $\begin{array}{c}\text { HRT } \\
\text { (days or h) }\end{array}$ & Treatment & \\
\hline 1. & $\begin{array}{l}\text { Current standard discharge } \\
\text { limit }\end{array}$ & 100 & 100 & 400 & 200 & 50 & - & - & - & - & - & $\begin{array}{l}\text { DOE, } \\
1982\end{array}$ \\
\hline 2. & Future standard discharge limit & - & 20 & 200 & 100 & 5 & - & - & - & - & - & $\begin{array}{l}\text { DOE, } \\
2015\end{array}$ \\
\hline 3. & $\begin{array}{l}\text { Mesophilic-thermophilic } \\
\text { bacterial seed }\end{array}$ & $99.60 \%$ & $99.00 \%$ & $99.00 \%$ & - & - & - & $45-68$ & 75 & $115 \mathrm{~d}$ & $\begin{array}{l}\text { Integrated } \\
\text { anaerobic-aerobic bioreactor } \\
\text { (IAAB). }\end{array}$ & [8] \\
\hline 4. & Thermophilic mixed culture & $90.00 \%$ & - & - & - & - & - & 64 & 2.5 & $6 \mathrm{~d}$ & $\begin{array}{l}\text { Anaerobic, } \\
\text { Continuous stirred tank } \\
\text { reactor (CSTR). }\end{array}$ & {$[40]$} \\
\hline 5. & Activated sludge basins & $96.00 \%$ & $99.00 \%$ & $99.00 \%$ & - & - & - & - & 1.8 & $22 \mathrm{~h}$ & $\begin{array}{l}\text { Aerobic, Sequencing batch } \\
\text { reactor (SBR). }\end{array}$ & [2] \\
\hline 6. & Anaerobic culture in POME & $98.90 \%$ & - & $93.00 \%$ & - & - & - & - & 200 & $7 \mathrm{~d}$ & $\begin{array}{l}\text { Ultra-sonic-assisted } \\
\text { Membrane Anaerobic } \\
\text { System (UMAS). }\end{array}$ & [41] \\
\hline 8. & $\begin{array}{l}\text { POME + inoculum from cow } \\
\text { manure digester farm }\end{array}$ & $92.00 \%$ & - & - & - & - & - & 30 & 5 & $25 \mathrm{~d}$ & $\begin{array}{l}\text { Anaerobic filter (AFR) with } \\
\text { immobilized bio-balls with } \\
\text { addition of Ni. }\end{array}$ & [62] \\
\hline 9. & $\begin{array}{l}\text { Microalgae } \\
\text { (Chlorella spp. UKM } 8 \text { and } \\
\text { Chlamydomonas sp. UKM 6) }\end{array}$ & $92.00 \%$ & - & - & - & - & $15.00 \%$ & - & 2 & $21 \mathrm{~d}$ & $\begin{array}{l}\text { Anaerobic, Carbon dioxide } \\
\text { fixation. }\end{array}$ & [53] \\
\hline 10. & $\begin{array}{l}\text { Micrococcus luteus 101PB, } \\
\text { Stenotrophomonas maltophilia } \\
\text { 102PB, Bacillus cereus 103PB, } \\
\text { Providencia vermicola 104PB, } \\
\text { Klebsiella pneumonia 105PB, } \\
\text { Bacillus subtilis 106PB, } \\
\text { Aspergillus fumigatus 107PF, } \\
\text { Aspergillus nomius 108PF, } \\
\text { Aspergillus niger 109PF, and } \\
\text { Meyerozyma guilliermondii 110PF }\end{array}$ & $91.06 \%$ & $90.23 \%$ & $92.23 \%$ & - & - & - & - & 1 & $50 \mathrm{~d}$ & $\begin{array}{l}\text { Aerobic mixed microbial } \\
\text { consortium for all } \\
\text { bacteria-fungi combination } \\
\text { (ABFC). }\end{array}$ & {$[63]$} \\
\hline
\end{tabular}


Table 2. Cont

\begin{tabular}{|c|c|c|c|c|c|c|c|c|c|c|c|c|}
\hline \multirow[b]{2}{*}{ No. } & \multirow[b]{2}{*}{$\begin{array}{c}\text { Microbes or } \\
\text { Biological Seeding }\end{array}$} & \multicolumn{6}{|c|}{ Concentration, mg/L or Removal Efficiency, \% } & \multirow[b]{2}{*}{$\begin{array}{c}\mathrm{CH}_{4} \\
\text { Release(\%) }\end{array}$} & \multicolumn{3}{|c|}{ Process Aspects } & \multirow[b]{2}{*}{ Ref } \\
\hline & & $\begin{array}{l}\text { COD } \\
(\mathrm{mg} / \mathrm{L})\end{array}$ & $\begin{array}{l}\text { BOD } \\
(\mathrm{mg} / \mathrm{L})\end{array}$ & $\begin{array}{c}\text { TSS } \\
(\mathrm{mg} / \mathrm{L})\end{array}$ & $\begin{array}{l}\text { Colour } \\
(\mathrm{mg} / \mathrm{L})\end{array}$ & $\begin{array}{l}\text { Oil } \\
(\mathrm{mg} / \mathrm{L})\end{array}$ & $\begin{array}{c}\mathrm{CO}_{2} \\
\text { Fixation } \\
\text { (g CO} 2 / \mathrm{L} / \text { day })\end{array}$ & & $\begin{array}{l}\text { Working } \\
\text { Volume } \\
\text { (L) }\end{array}$ & $\begin{array}{c}\text { HRT } \\
\text { (days or h) }\end{array}$ & Treatment & \\
\hline 12. & Thermophilic mixed culture & $90.00 \%$ & $58.07 \%$ & $55.44 \%$ & 26.20 & - & - & $325 \mathrm{~mL}$ & - & - & Anaerobic digestion & [65] \\
\hline 13. & $\begin{array}{l}\text { Fungal strains Emericella } \\
\text { ridulans NFCCI } 3643\end{array}$ & $90.00 \%$ & $88.23 \%$ & - & - & $87.34 \%$ & - & - & 0.25 & $5 d$ & $\begin{array}{l}\text { Aerobic Fermentation } \\
\text { (Shake flasks) }\end{array}$ & [66] \\
\hline 14. & Thermophilic mixed culture & $86.30 \%$ & $97.30 \%$ & $98.30 \%$ & - & - & - & 52 & 4.5 & $36 \mathrm{~d}$ & $\begin{array}{l}\text { Anaerobic, Upflow } \\
\text { anaerobic sludge } \\
\text { blanket-hollow centred } \\
\text { packed bed (UASB-HCPB) } \\
\text { reactor }\end{array}$ & [9] \\
\hline 15. & Saccharomyces cerevisiae strain & $85.00 \%$ & $91.00 \%$ & $89.00 \%$ & - & - & - & - & 2 & $17 \mathrm{~d}$ & $\begin{array}{l}\text { Anaerobic fluidised bed } \\
\text { reactor (AFBR) }\end{array}$ & [67] \\
\hline 16. & Moringa oleifera extract & $76.00 \%$ & $94.00 \%$ & $92.24 \%$ & - & $91.90 \%$ & - & 69 & 0.45 & $30 \mathrm{~d}$ & Anaerobic co-digestion. & [68] \\
\hline 18. & Activated sludge treatment & $68.00 \%$ & $65.00 \%$ & - & - & - & - & - & 2 & $6 \mathrm{~d}$ & Anaerobic treatment & [69] \\
\hline 19. & Raw POME & $59.00 \%$ & $80.76 \%$ & - & - & - & - & 57 & $5 \mathrm{~m}^{3}$ & 11 months & $\begin{array}{l}\text { Aerobic BioAX treatment, } \\
\text { AnaerobicEG bioreactors } \\
\text { (Pilot scale bioreactor) }\end{array}$ & [70] \\
\hline 20. & $\begin{array}{l}\text { Thermophilic anaerobic-aerobic } \\
\text { treated POME }\end{array}$ & $53.10 \%$ & - & $88.00 \%$ & $79.00 \%$ & - & - & - & 1 & - & $\begin{array}{l}\text { Pectin and chitosan in Jar } \\
\text { Test protocol. }\end{array}$ & [71] \\
\hline 21. & POME + dairy manure & $48.00 \%$ & - & - & - & - & - & 59 & 7 & $10 \mathrm{~d}$ & $\begin{array}{l}\text { Continous stirred tank } \\
\text { reactor (CSTR). }\end{array}$ & [72] \\
\hline 22. & $\begin{array}{l}13 \text { phyla of bacteria } \\
\text { (Proteobacteria, Chloroflexi, } \\
\text { Firmicutes, Bacteroidetes, and } \\
\text { Nitrospirae) }\end{array}$ & $48.00 \%$ & - & - & - & - & - & - & 1 & $3 \mathrm{~d}$ & $\begin{array}{l}\text { Moving bed biofilm reactor } \\
\text { (MBBR). }\end{array}$ & [73] \\
\hline 23. & Typha latifolia & $97.18 \%$ & - & - & - & - & - & - & - & $9 \mathrm{~d}$ & $\begin{array}{l}\text { Phytoremediation using } \\
\text { single plant. }\end{array}$ & [44] \\
\hline 24. & Vetiveria zizanioides & $94.00 \%$ & $90.00 \%$ & - & - & - & - & - & 45 & $14 \mathrm{~d}$ & $\begin{array}{l}\text { Phytoremediation using } \\
\text { single plant. }\end{array}$ & [15] \\
\hline
\end{tabular}


Table 2. Cont.

\begin{tabular}{|c|c|c|c|c|c|c|c|c|c|c|c|c|}
\hline \multirow[b]{2}{*}{ No. } & \multirow[b]{2}{*}{$\begin{array}{c}\text { Microbes or } \\
\text { Biological Seeding }\end{array}$} & \multicolumn{6}{|c|}{ Concentration, mg/L or Removal Efficiency, \% } & \multirow[b]{2}{*}{$\begin{array}{c}\mathrm{CH}_{4} \\
\text { Release }(\%)\end{array}$} & \multicolumn{3}{|c|}{ Process Aspects } & \multirow[b]{2}{*}{ Ref } \\
\hline & & $\begin{array}{l}\text { COD } \\
(\mathrm{mg} / \mathrm{L})\end{array}$ & $\begin{array}{l}\text { BOD } \\
(\mathrm{mg} / \mathrm{L})\end{array}$ & $\begin{array}{c}\text { TSS } \\
(\mathrm{mg} / \mathrm{L})\end{array}$ & $\begin{array}{l}\text { Colour } \\
(\mathrm{mg} / \mathrm{L})\end{array}$ & $\begin{array}{l}\text { Oil } \\
(\mathrm{mg} / \mathrm{L})\end{array}$ & $\begin{array}{c}\mathrm{CO}_{2} \\
\text { Fixation } \\
\left.\text { (g CO } \mathrm{CO}_{2} / \mathrm{L} / \text { day }\right)\end{array}$ & & $\begin{array}{l}\text { Working } \\
\text { Volume } \\
\text { (L) }\end{array}$ & $\begin{array}{c}\text { HRT } \\
\text { (days or h) }\end{array}$ & Treatment & \\
\hline 25. & $\begin{array}{l}\text { Water spinach } \\
\text { (Ipomoea aquatic Forsk) }\end{array}$ & $86.30 \%$ & - & - & $95.30 \%$ & - & - & - & 10 & $15 \mathrm{~d}$ & $\begin{array}{l}\text { Phytoremediation using } \\
\text { single plant. }\end{array}$ & [45] \\
\hline 26. & Spirogyra sp. & $63.60 \%$ & - & - & - & - & - & - & 0.75 & $20 \mathrm{~d}$ & $\begin{array}{l}\text { Phytoremediation using } \\
\text { single plant. }\end{array}$ & [46] \\
\hline 27. & Pistia stratoites & $30.00 \%$ & $93.00 \%$ & - & - & - & - & - & 6 & $15 \mathrm{~d}$ & $\begin{array}{l}\text { Phytoremediation using } \\
\text { single plant. }\end{array}$ & {$[51]$} \\
\hline 28. & Eichorniacrassipes & $50.00 \%$ & $50.00 \%$ & - & - & - & - & - & 5 & $30 \mathrm{~d}$ & $\begin{array}{l}\text { Phytoremediation using } \\
\text { single plant. }\end{array}$ & [52] \\
\hline 29. & Bacillus cereus MF661883 & $79.35 \%$ & $72.65 \%$ & - & - & - & - & - & 0.2 & $6 \mathrm{~d}$ & $\begin{array}{l}\text { Batch fermentation mode, } \\
\text { lipid accumulation and } \\
\text { bioremediation. }\end{array}$ & [16] \\
\hline 30. & Aspergillus niger ATCC 9642 & $63.00 \%$ & - & - & - & - & - & - & 1 & $7 \mathrm{~d}$ & $\begin{array}{l}\text { Fermentation of POME into } \\
\text { citric acid. }\end{array}$ & [56] \\
\hline 31. & $\begin{array}{l}\text { Raw POME and anaerobic } \\
\text { sludge }\end{array}$ & $70.00 \%$ & - & - & - & - & - & - & 0.45 & $15 \mathrm{~d}$ & $\begin{array}{l}\text { Microbial fuel cell-dual } \\
\text { chamber }\end{array}$ & [59] \\
\hline
\end{tabular}




\subsection{Physicochemical Treatment}

Although there are various types of biological treatment, certain processes or systems may not deliver the required results with respect to the minimum requirements set by the authority. Physicochemical treatment processes or also known as polishing techniques are viable means to treat POME. Biomass and other waste materials such as fibres and fruits wastes may offer an inexpensive and renewable source for POME treatment. These waste materials have low or no economic value and often present a disposal problem. Therefore, there is a need to valorise these low-cost by-products. Thus, their conversion into sorbent for removing or/and reducing oil, BOD, COD, and Total Suspended Solid (TSS) from POME has an economic value to reduce the cost of waste disposal. Most importantly, these provide a potentially inexpensive alternative treatment technique. A wide variety of sorption materials was known for treatment of biomass and other wastes by using esterified sago bark fibre [17], activated bioadsorbent from oil palm kernel shell [74-76], banana peel [5,77], empty fruit bunch (EFB) [78,79], coconut shell [80,81], oil palm mesocarp fibre [82], rice husk [83] and cocoa peels [84]. Currently, natural fibres are considered as highly potential sources to be utilized as natural sorbents for removing oil from POME with excellent adsorption properties, as well as being chemical-free and highly biodegradable [85].

Table 3 shows the summary of various bioadsorbent materials prepared from biomass, which exhibit high sorption properties. Mohammed and Chong [5] reported that the highest COD (100\%), BOD (97\%), TSS (100\%), and colour removal (96\%) were obtained after $30 \mathrm{~h}$ treatment by banana peel adsorbent dosage of $30 \mathrm{~g} / 100 \mathrm{~mL}$. A well-known biosorbent material such as industrial-grade alum at $10 \mathrm{~g} / \mathrm{L}$ dosage was reported in reducing the COD (98\%) and TSS (99\%) value in 25\% v/v POME [78]. An empty fruit bunch-based activated carbon with a dosage of $20 \mathrm{~g} / \mathrm{L}$ was utilized to treat POME, significantly reducing the COD, BOD, and TSS at $98 \%, 88 \%$, and $96 \%$ within only $30 \mathrm{~min}$ [79]. Mohammed [74] successfully removed the POME colour $(100 \%)$ within $12 \mathrm{~h}$ by using oil palm kernel shell (PKS), followed by chemical activation (potassium hydroxide) and microwave treatment. The high feasibility in adsorption method especially in oil removal was also reported using esterified sago bark fiber and sago bark fibre [17]. Those performances were evaluated using adsorption tests particularly for $24 \mathrm{~h}$, resulting in $80.23 \%$ and $57.77 \%$, respectively. However, no analysis of COD and BOD was done in this work. Based on the compiled literature, we conclude that until now, there is no further investigations on the POME adsorption scalability.

Alternative physicochemical treatments such as membrane filtration $[4,18,86]$, coagulation [87], coagulation-flocculation [88-90], electrocoagulation [91-93], and fentonoxidation [94-96] were only capable of migrating the organic pollutants from one form into another. However, those still could not mineralise the organic pollutants [97]. These methods are considered to be costly due to the chemical usage and involved excess-sludge treatment [98]. Worldwide, membrane techniques have been extensively used in POME polishing treatments prior to reducing the concentration of COD, BOD, TSS, colour, and any organic elements. Membrane usage such as nanofiltration, ultrafiltration, and reverse osmosis were capable to increase the removal efficiencies of pollutants $[4,18,86]$. Ahmad et al. [4] utilized membrane filtration with success to remove more than $99.40 \%$ of COD, $98.80 \%$ of BOD, with $100 \%$ of TSS removal within $4 \mathrm{~h}$ of treatment for $200 \mathrm{~mL}$ POME. Azmi and Yunos [18] adopted micro filtration membrane (MF) method applying for POME with COD and BOD reduction in $180 \mathrm{~mL}$ POME at $90 \%$ within 1.5 days. Amat et al. [86] successfully decolourised POME at 97.40-97.90\% removal with MF system throughout $4 \mathrm{~h}$ for a volume of $15 \mathrm{~mL}$ of POME. Several researchers evaluated the removal of pollutants from POME final discharge by using membrane bioreactor (MBR), as classified as a hybrid system of two interdependent processes of biological and membrane filtration [99]. An integrated treatment process for POME final discharge was based on MBR adopted by Ahmed and co-workers [20] for obtaining high quality effluent. However, the major problem when using the membrane is generally caused by pore blocking at the membrane surface, which simultaneously affects the capital cost and maintenance [100]. 
Coagulation-flocculation process is acknowledged to have a superior performance technology in filtering the suspended solids [89]. More than $90 \%$ of colour removal was achieved within 23 min of POME decolourisation using dual-coagulants, ferric chlorideanionic polyacrylamide [30]. The coagulant is basically composed of chemical compounds, as they are easy to handle, cheap, and portray good removal efficiency towards the wastewater application [101]. Another study utilised mango pit as a coagulant and fly ash as an adsorbent in the coagulation-flocculation process [88] and recorded COD and TSS removal at $89 \%$ and $96 \%$ within $1 \mathrm{~h}$. Through the coagulation process or other tertiary treatment processes, the capability of adsorption process in removing the pollutants is potentially high. Therefore, the combination with other treatment techniques would enhance the performance of POME treatment. However, after treatment of the flocculation process, huge sludge remained as an additional problem.

Electrochemical processes including electrolysis and electrocoagulation techniques have been effectively employed for removing pollutants in various industrial wastewaters [102]. The latter process is claimed to be an effective wastewater treatment technique, as it involves a series of treatments: coagulation, precipitation, and flotation. Electrocoagulation uses aluminium or iron anodes to produce aluminium or iron hydroxide flocs by the hydrolysis reaction of the anodes. The ability in treating POME was studied on the decolourisation through the polishing step [91,92], resulting in almost $100 \%$ colour removal being recorded in POME decolourisation utilizing aluminium electrode within 65 min operation. Che Sayuti and Mohd Azoddein [91] successfully reduced the COD from $4900 \mathrm{mg} / \mathrm{L}$ to $210 \mathrm{mg} / \mathrm{L}(95.71 \%)$ and TSS from $4000 \mathrm{mg} / \mathrm{L}$ to $30 \mathrm{mg} / \mathrm{L}(99.25 \%)$, respectively. The final COD value almost met the DOE requirement of $200 \mathrm{mg} / \mathrm{L}$, whereas TSS was $100 \mathrm{mg} / \mathrm{L}$, completely fitting the requirement. The highest efficiency was obtained at optimum $\mathrm{pH} 7.44$ with electrocoagulation time of $25 \mathrm{~min}$ and voltage of $100 \mathrm{~V}$ utilising aluminium electrodes. Interestingly, this method was found to be efficient and capable in reducing treatment time compared to the ponding system.

Electron-Fenton system demonstrated better performance to COD removal than the electrocoagulation system, despite both being capable in reducing most of the organic compounds [101]. Fenton-oxidation has become another favourable treatment system in the past decades [103]. For example, a total of $85 \%$ COD reduction was achieved under the acidic POME at a pH close to 3. For the decolourisation and organic decomposition [104], Fenton-oxidation process was useful, resulting in a higher COD removal $(82 \%)$, with more than $90 \%$ colour removal in the case of $50 \mathrm{mM} \mathrm{H}_{2} \mathrm{O}_{2}$ with $\mathrm{Fe}^{2+}$ for the $30 \mathrm{~min}$ oxidation process.

In other studies, ultrasonic cavitation technology, coupled with the use of hydrogen peroxide, $\mathrm{H}_{2} \mathrm{O}_{2}$, was used as an alternative technique in treating POME [104]. Cavitation is defined as the phenomenon of formation, growth, and collapse of microbubbles in a specific liquid. There are several types of cavitation, described as acoustic, hydrodynamic, optic, and particle. The application of ultrasonic cavitation was widely employed for degradation of textile dyes [105], degradation of chemical contaminants [106], and industrial wastewater treatment [107]. Manickam et al. [108] successfully investigated the effect of hydrogen peroxide in reducing the COD patterns by using the combination of ultrasound $/ \mathrm{H}_{2} \mathrm{O}_{2}$ $(30 \% w / v)$, yielding better results compared to ultrasound $/ \mathrm{H}_{2} \mathrm{O}_{2}(6 \% w / v)$. An impressive result was obtained at final COD of $27,000 \mathrm{mg} / \mathrm{L}$ (almost $50 \%$ reduction) for $6 \mathrm{~h}$. Thus, the final COD obtained portrayed the suitability method of chemical/ultrasound combination as a pre-treatment step for POME, as followed by another digestion method. In addition to COD reduction, POME de-colouring was possible from brown to light yellow with this treatment. Thus, it was believed that this technique could be one of the green process engineering techniques for POME treatment [108].

Photocatalytic reaction demonstrates high efficiency in the degradation of organic compounds [109]. $\mathrm{TiO}_{2}$ are the most widely utilized owing to its low cost, low toxicity, high performance, and high chemical stability. The heterogenous photocatalytic system used $\mathrm{TiO}_{2}$ nanoparticles as the photocatalyst, and simultaneously performed better in 
degrading the organic pollutants, especially in POME $[110,111]$. The COD reduction $(78 \%)$ was obtained from the initial value of $168 \mathrm{mg} / \mathrm{L}$ in POME settling pond [111]. Organic compounds in POME were successfully decomposed within $7 \mathrm{~h}$ or reaction by using $0.83 \mathrm{~g} / \mathrm{L}$ of $20 \% \mathrm{wt}$. $\mathrm{Cu} / \mathrm{TiO}_{2}$ loading [112]. Despite their advantages, the photocatalytic system also portrayed several drawbacks such as inefficient catalyst separation and low penetration of light incident during the reaction. Thus, some modifications including cylindrical column photoreactor [109], double-cylindrical shell photoreactor [113], and ZSM-5 zeolite support with $\mathrm{Fe}^{3+}$ and $\mathrm{Ni}^{2+}$ doping [114] could overcome their problems. By introducing steam-high temperature, Cheng et al. [115] and $\mathrm{Ng}$ et al. [116] successfully generated novel approaches for catalytic POME steam, reforming into a valuable syngas. In the former, the highest COD and BOD removals were achieved at $93.8 \%$ and $93.7 \%$, respectively, at $873 \mathrm{~K}$ and $51.44 \%$ of $\mathrm{H}_{2}$ selectivity under $90 \mathrm{~mL} / \mathrm{h}$ POME flow in $20 \mathrm{~mL} / \mathrm{min}$ of $\mathrm{N}_{2}$ as the carrier gas. In the latter, $99.7 \%$ of COD was reduced over the same catalyst at $1173 \mathrm{~K}$ within $1 \mathrm{~h}$ of operation. It was apparent that high temperature and partial pressure of POME favoured higher $\mathrm{H}_{2}$ production. Despite the potential of $\mathrm{H}_{2}$ gas production, the energy consumption and net energy in transforming the POME into syngas should be furthermore verified to identify the scale-up feasibility prospect.

\subsection{Thermochemical Treatment}

Thermochemical treatment was one of the prominent ways to transform the wet biomass into valuable products, as also known by 'synthesis gas' with abbreviation of syngas. By using the minimization of total Gibbs free energy method, the thermodynamic simulation is performed to study the effect of reaction temperature on product yield and syngas ratio $\left(\mathrm{H}_{2}: \mathrm{CO}\right)$ [117]. The result evinced the steam reforming all POME organic compounds, which is feasible at $773 \mathrm{~K}$ and beyond this point. Bioconversion of the highest $\mathrm{H}_{2}$-rich syngas occurred at $1073 \mathrm{~K}$ within the study temperature ranging from 573-1173 K [117].

The supercritical water gasification (SCWG) was conducted at $653 \mathrm{~K}$ with 250 bar prior to obtaining syngas from the dual feed of POME and empty fruit bunch (EFB) [118]. The POME served as the reaction medium, whereas the EFB acted as the main substrate. The pure POME was gasified into the valuable gaseous products yielding about $13 \mathrm{mmol} / \mathrm{mL}$ of $\mathrm{CO}_{2}, 20 \mathrm{mmol} / \mathrm{mL}$ of $\mathrm{H}_{2}, 0.3 \mathrm{mmol} / \mathrm{min}$ of $\mathrm{CH}_{4}$, and $0.6 \mathrm{mmol} / \mathrm{mL} \mathrm{CO}$, respectively. Evidently POME had high potential substrate in producing valuable and beneficial gas products under SCWG condition.

In spite of the substantially enhanced $\mathrm{H}_{2}$ gas production, the carbon deposition on the catalyst surface may deter the overall process. In addition, in order to efficiently perform this process at a large-scale, the reduction of overall energy consumption to produce syngas should be addressed. 
Table 3. Summary of various physicochemical treatments at different dosages with removal efficiency of final discharge POME.

\begin{tabular}{|c|c|c|c|c|c|c|c|c|c|c|c|c|}
\hline \multirow[b]{2}{*}{ No. } & \multirow[b]{2}{*}{ Bioadsorbent Material } & \multirow[b]{2}{*}{$\begin{array}{l}\text { Bioadsorbent } \\
\text { Dosage (g/L) }\end{array}$} & \multicolumn{6}{|c|}{ Concentration, mg/L or Removal Efficiency, $\%$} & \multicolumn{3}{|c|}{ Process Aspects } & \multirow[b]{2}{*}{ Ref. } \\
\hline & & & $\begin{array}{c}\text { COD } \\
(\mathrm{mg} / \mathrm{L})\end{array}$ & $\begin{array}{c}\text { BOD } \\
(\mathrm{mg} / \mathrm{L})\end{array}$ & $\begin{array}{c}\text { TSS } \\
(\mathrm{mg} / \mathrm{L})\end{array}$ & $\begin{array}{l}\text { Colour } \\
(\mathrm{mg} / \mathrm{L})\end{array}$ & $\begin{array}{c}\text { Oil } \\
(\mathrm{mg} / \mathrm{L})\end{array}$ & $\begin{array}{c}\mathrm{CH}_{4} \\
\text { Release } \\
(\%) \\
\end{array}$ & $\begin{array}{l}\text { Working } \\
\text { Volume } \\
\text { (L) }\end{array}$ & $\begin{array}{c}\text { HRT } \\
\text { (day/h/min) }\end{array}$ & Treatment & \\
\hline 1. & Standard discharge limit & - & 100 & 100 & 400 & 200 & 50 & - & - & - & - & DOE, 1982 \\
\hline 2. & Future discharge limit & - & - & 20 & 200 & 100 & 5 & - & - & - & - & DOE, 2015 \\
\hline 3. & Esterified sago bark fibre & 5 & - & - & - & - & $80.23 \%$ & - & 0.1 & $24 \mathrm{~h}$ & $\begin{array}{l}\text { Ethyl acetate and } \\
\text { calcium oxide. }\end{array}$ & [17] \\
\hline 4. & Oil palm kernel shell & $5 \mathrm{~g} / 100 \mathrm{~mL}$ & - & - & - & $100 \%$ & - & - & 0.1 & $14 \mathrm{~h}$ & $\begin{array}{l}\text { Potassium hydroxide } \\
\text { activation, and } \\
\text { microwave. }\end{array}$ & {$[74]$} \\
\hline 5. & Banana peel & $30 \mathrm{~g} / 100 \mathrm{~mL}$ & $100 \%$ & $97.00 \%$ & $100 \%$ & $96.00 \%$ & - & - & 0.1 & $30 \mathrm{~h}$ & $\begin{array}{l}\text { Activated carbon } \\
(\mathrm{AC}) \text {. }\end{array}$ & [5] \\
\hline 6. & Industrial grade alum & 10 & $98.00 \%$ & - & $99.00 \%$ & - & - & - & 1.0 & - & $\begin{array}{l}\text { Adsorption- } \\
\text { coagulation }\end{array}$ & [78] \\
\hline 7. & $\begin{array}{l}\text { Empty fruit bunch-based } \\
\text { activated carbon }\end{array}$ & 20 & $98.00 \%$ & $88.00 \%$ & $96.00 \%$ & - & - & - & 0.1 & $30 \mathrm{~min}$ & $\begin{array}{l}\text { Pyrolysis, followed by } \\
\text { physical activation. }\end{array}$ & [79] \\
\hline 8. & Oil palm kernel shell & 10 & $89.00 \%$ & $85.00 \%$ & $80.00 \%$ & $88.00 \%$ & - & - & - & - & $\begin{array}{l}\text { Sodium-potassium } \\
\text { hydroxide mixture } \\
\text { (NaOH-KOH) } \\
\text { activation. }\end{array}$ & [75] \\
\hline 9. & Oil palm kernel shell & - & $80.00 \%$ & - & - & - & - & - & 0.25 & $24 \mathrm{~h}$ & Steaming & [76] \\
\hline 10. & Coconut shell & 50 & $70.00 \%$ & - & $70.00 \%$ & $70.00 \%$ & - & - & - & $30 \mathrm{~h}$ & $\begin{array}{l}\text { Commercial activated } \\
\text { carbon }\end{array}$ & {$[80]$} \\
\hline 11. & Oil palm mesocarp fibre & 10 & $70.00 \%$ & - & $88.00 \%$ & - & - & - & - & - & $\begin{array}{l}\text { Consecutive } \\
\text { treatments. }\end{array}$ & {$[82]$} \\
\hline 12. & Coconut shell & 5 & $61.00 \%$ & - & $39.00 \%$ & $61.00 \%$ & - & - & 0.1 & $48 \mathrm{~h}$ & $\begin{array}{l}\text { Acid-washed activated } \\
\text { carbon (Kinetic } \\
\text { models) }\end{array}$ & [81] \\
\hline 13. & $\begin{array}{l}\text { Fruit peel (banana and } \\
\text { orange peels) }\end{array}$ & 10 & $52.00 \%$ & $46.00 \%$ & $18.00 \%$ & $57.00 \%$ & - & - & - & 3 days & $\begin{array}{l}\text { Biochar from pyrolysis } \\
\text { of fruit peels. }\end{array}$ & [77] \\
\hline
\end{tabular}


Table 3. Cont

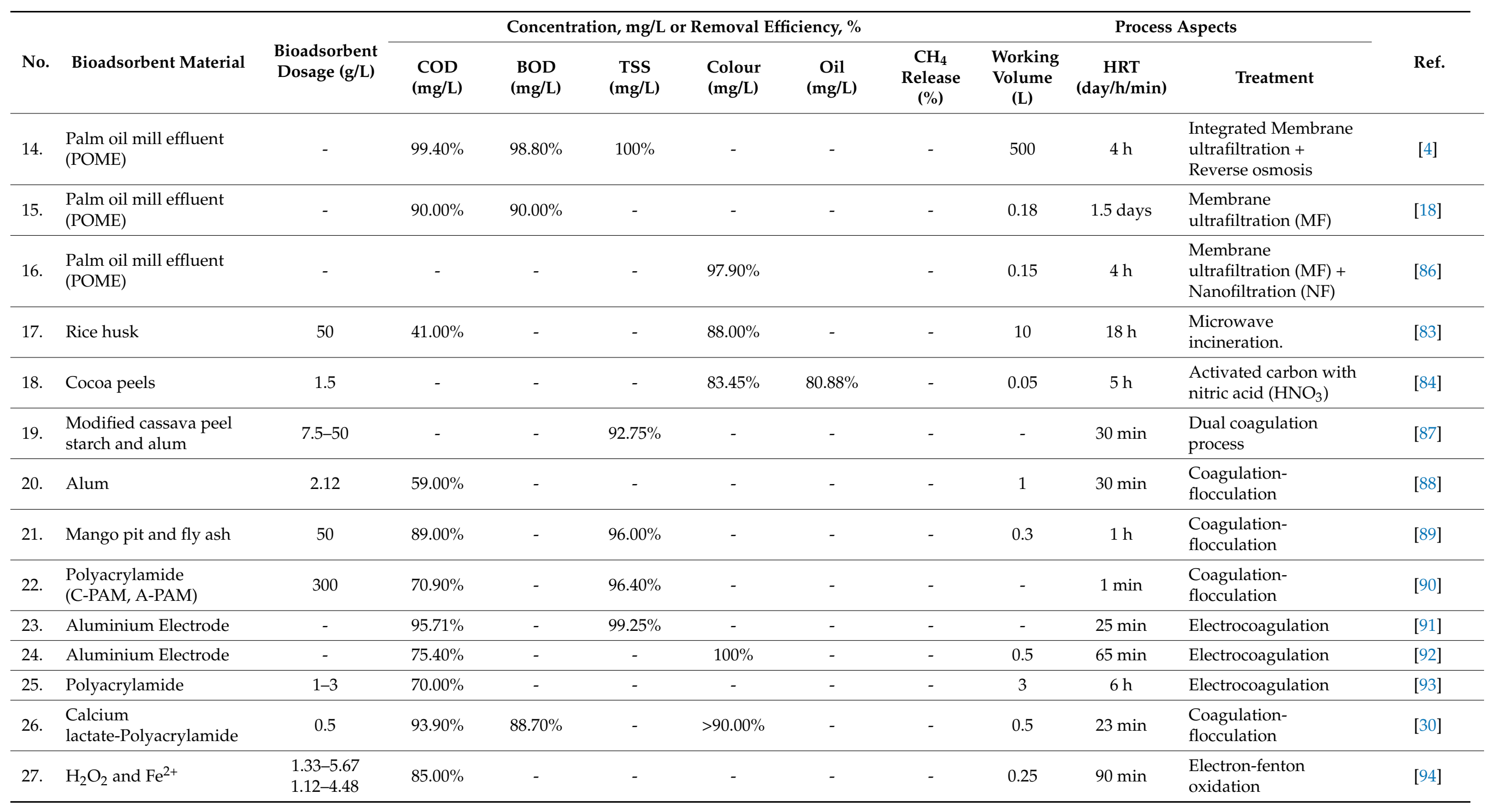


Table 3. Cont.

\begin{tabular}{|c|c|c|c|c|c|c|c|c|c|c|c|c|}
\hline \multirow[b]{2}{*}{ No. } & \multirow[b]{2}{*}{ Bioadsorbent Material } & \multirow[b]{2}{*}{$\begin{array}{l}\text { Bioadsorbent } \\
\text { Dosage (g/L) }\end{array}$} & \multicolumn{6}{|c|}{ Concentration, mg/L or Removal Efficiency, \% } & \multicolumn{3}{|c|}{ Process Aspects } & \multirow[b]{2}{*}{ Ref. } \\
\hline & & & $\begin{array}{l}\text { COD } \\
(\mathrm{mg} / \mathrm{L})\end{array}$ & $\begin{array}{l}\text { BOD } \\
(\mathrm{mg} / \mathrm{L})\end{array}$ & $\begin{array}{c}\text { TSS } \\
(\mathrm{mg} / \mathrm{L})\end{array}$ & $\begin{array}{l}\text { Colour } \\
\text { (mg/L) }\end{array}$ & $\begin{array}{c}\text { Oil } \\
(\mathrm{mg} / \mathrm{L})\end{array}$ & $\begin{array}{c}\mathrm{CH}_{4} \\
\text { Release } \\
(\%)\end{array}$ & $\begin{array}{l}\text { Working } \\
\text { Volume } \\
\text { (L) }\end{array}$ & $\begin{array}{c}\text { HRT } \\
\text { (day/h/min) }\end{array}$ & Treatment & \\
\hline 28. & $\mathrm{H}_{2} \mathrm{O}_{2}$ and $\mathrm{Fe}^{2+}$ & $\begin{array}{c}5.0 \mathrm{mM}, 1.0 \\
\mathrm{mM}\end{array}$ & $82.00 \%$ & - & - & - & - & - & 0.25 & $30 \mathrm{~min}$ & $\begin{array}{l}\text { Electron-fenton } \\
\text { oxidation }\end{array}$ & [104] \\
\hline 29. & $\mathrm{H}_{2} \mathrm{O}_{2}$ & 10 & $50.00 \%$ & - & - & - & - & - & 0.05 & $6 \mathrm{~h}$ & $\begin{array}{l}\text { Ultrasonic cavitation } \\
\text { coupled with } \mathrm{H}_{2} \mathrm{O}_{2}\end{array}$ & [108] \\
\hline 31. & $\mathrm{Cu} / \mathrm{TiO}_{2}$ & 0.83 & $40.00 \%$ & - & - & - & & - & 0.3 & $7 \mathrm{~h}$ & $\begin{array}{l}\mathrm{Cu}-\mathrm{TiO}_{2} \text { photocatalytic } \\
\text { reaction }\end{array}$ & [112] \\
\hline 32. & $\mathrm{Ni} / \mathrm{Al}_{2} \mathrm{O}_{3}$ & 0.1 & $93.80 \%$ & $93.70 \%$ & - & - & - & $0.6-3.3$ & 40 & $5 \mathrm{~h}$ & $\begin{array}{l}\text { Photocatalytic by } \\
\text { steam } \\
(873 \mathrm{~K})\end{array}$ & [116] \\
\hline 33. & $\mathrm{Ni} / \mathrm{Al}_{2} \mathrm{O}_{3}$ & 0.1 & $99.70 \%$ & - & - & - & - & 0.28 & - & $1 \mathrm{~h}$ & $\begin{array}{l}\text { Photocatalytic by } \\
\text { steam } \\
(1173 \mathrm{~K})\end{array}$ & [117] \\
\hline 34. & Palm oil mill effluent & 50 & $73.08 \%$ & - & $98.33 \%$ & - & - & - & - & $6 \mathrm{~h}$ & $\begin{array}{l}\text { Activated carbon (AC) } \\
\text { and ultrasound (US). }\end{array}$ & [119] \\
\hline 35. & $\begin{array}{l}\text { Cultures of Aspergillus } \\
\text { fumigatus }\end{array}$ & $10 \%$ & $71.00 \%$ & - & - & $71.00 \%$ & - & - & 0.01 & 5 days & $\begin{array}{l}\text { Different carbon } \\
\text { sources- } \\
\text { centrifugation. }\end{array}$ & [120] \\
\hline 36. & $\begin{array}{l}\text { Palm oil mill effluent } \\
\text { (POME) }\end{array}$ & $5-20$ & $46.00 \%$ & - & $61.00 \%$ & $39.00 \%$ & - & - & 0.1 & $6 \mathrm{~h}$ & $\begin{array}{l}\text { Combined magnetic } \\
\text { field and commercial } \\
\text { activated carbon } \\
\text { (adsorption) }\end{array}$ & [121] \\
\hline
\end{tabular}




\subsection{Torrefaction or Hydrothermal Treatment}

Conversion of solid waste to high-density briquettes via torrefaction or hydrothermal as a pre-treatment process is touted as the ideal solution to avert accumulation of solid waste, especially in the agro-industry sector. Various agro-industry solid wastes such as woodchips, olive pulp, and olive stones are pre-treated to produce biomass fuel with a heating value (HV) ranging from 16.7-20.3 MJ/ $\mathrm{kg}$ [122,123]. In lieu of the aforementioned pre-treatment process, the mixture of POME and oil palm trunk (OPT) is simply subjected to being oven dried at $105^{\circ} \mathrm{C}$ until constant weight is observed and followed by forming into briquettes [124]. POME and OPT with the ratio 90:10 bode the highest $\mathrm{HV}$ of $30.85 \mathrm{MJ} / \mathrm{kg}$ [124]. The high HV value obtained by utilizing POME corroborates its potential applications for biomass fuel, as compared to other agro-wastes.

\section{Life Cycle Analysis of POME}

Life cycle analysis (LCA) is a common method used for assessing environmental impacts associated with new technology designs or processes, herein specifically focused on various POME treatments. The severity of environmental impact upon utilizing the designated POME treatment processes can be quantitatively evaluated by monitoring the parameters such as level of $\mathrm{BOD}, \mathrm{COD}$, and $\mathrm{CO}_{2}$ emissions. Among all mooted POME treatment processes listed in Tables 2 and 3, only the biological treatment utilizing an integrated anaerobic-aerobic bioreactor in the presence of mesophilic-thermophilic bacterial and physicochemical treatment, using banana peel as a bioadsorbent material, can be categorized as the most efficient process. The utilization of agro-waste such as banana peel and EFB as bioadsorbent are deemed to be cost-efficient. The aforementioned waste material has no economic value and is often present as a voluminous solid waste. Thus, valorization of these by-products will aid in reducing the waste disposal costs and creating other value-added products such as bioadsorbents.

\section{Conclusions}

Overall, among the aforementioned POME treatments, phytoremediation, MFC techniques, and agro-waste-derived bioadsorbents seemed to be more cost-effective, but still were unable to produce satisfactory results in lowering the COD and BOD values. Numerous physicochemical treatment methods of biological processes, bioadsorbents, membranes, and coagulants were employed for treating POME, but no single process can be utilized as stand-alone at the commercial scale, yet. The usage of these adsorbents and chemical coagulants seems uneconomical and impractical. The thermochemical treatment for POME including the integrated system of anaerobic-aerobic bioreactor (IAAB) demonstrated the highest COD removal efficiency and is touted as the ideal treatment system. The judicious utilization of various affordable biomaterials, short treatment time, and scalable and clean technologies will be expected to pave the way towards an efficient POME treatment. These initiatives are in line with United Nations Sustainable Development Goals 7: Affordable and clean energy. Finally, we wish to comment on the sustainable aspect. Most treatment technologies should deem to possess environment-friendly properties to some extent, either partially or, preferably, through elimination of chemical solvent usage. Their many advantageous characteristics of biological treatment over harmful chemical utilization justify their use as an eco-friendly treatment process.

Author Contributions: Conceptualization, S.B.; validation, S.B. and T.K.; formal analysis, S.M.; investigation, S.M. and S.B.; resources, S.B., T.K., N.I. and C.P.L.; writing-original draft preparation, S.B.; writing-review and editing, S.B., T.K., N.I. and C.P.L.; supervision, S.B.; funding acquisition, S.B. and T.K.; All authors have read and agreed to the published version of the manuscript.

Funding: This research paper was funded by Universiti Sains Malaysia via External Research Grant (Grant No.: 304/PTEKIND/6501005/N126) and GAICCE project from ASEAN University Network/Southeast Asia Engineering Education Development Network (AUN/SEED-Net) (Grant No.: CEP 1901). 
Institutional Review Board Statement: Not applicable.

Informed Consent Statement: Not applicable.

Data Availability Statement: Not applicable.

Acknowledgments: Authors would like to express gratitude to the staff of United Oil Palm Industries Sdn. Bhd. Nibong Tebal, Penang, Malaysia for their helpful advice and technical assistance concerning the data compilation of POME pond treatment.

Conflicts of Interest: The authors declare no conflict of interest.

$\begin{array}{ll}\text { Abbreviations } \\ \text { POME } & \text { Palm oil mill effluent } \\ \text { IAAB } & \text { Integrated anaerobic-aerobic bioreactors } \\ \text { BOD } & \text { Biochemical oxygen demand } \\ \text { COD } & \text { Chemical oxygen demand } \\ \text { TSS } & \text { Total suspended solids }\end{array}$

\section{References}

1. Kamyab, H.; Chelliapan, S.; Md Din, M.F.; Rezania, S.; Khademi, T.; Nadda, A. Palm Oil Mill Effluent as an Environmental Pollutant; IntechOpen: London, UK, 2018; pp. 13-28. ISBN 978-1-78923-426-8.

2. Chan, Y.J.; Chong, M.F.; Law, C.L. Biological treatment of anaerobically digested Palm Oil Mill Effluent (POME) using a Lab-Scale Sequencing Batch Reactor (SBR). J. Environ. Manag. 2010, 91, 1738-1746. [CrossRef]

3. Ma, A.N. Treatment of palm oil mill effluent. In Oil Palm and the Environment: A Malaysian Perspective; Singh, G., Lim, K.H., Leng, T., David, L.K., Eds.; Malaysian Oil Palm Growers' Council: Kuala Lampur, Malaysia, 1999; pp. 113-126.

4. Latif Ahmad, A.; Ismail, S.; Bhatia, S. Water recycling from Palm Oil Mill Effluent (POME) using membrane technology. Desalination 2003, 157, 87-95. [CrossRef]

5. Mohammed, R.R.; Chong, M.F. Treatment and decolorization of biologically treated Palm Oil Mill Effluent (POME) using banana peel as novel biosorbent. J. Environ. Manag. 2014, 132, 237-249. [CrossRef]

6. Hwang, T.K. Chemical composition of palm oil mill effluents. Planter 1978, 54, 749-756.

7. Rana, S.; Singh, L.; Wahid, Z.; Liu, H. A recent overview of palm oil mill effluent management via bioreactor configurations. Curr. Pollut. Rep. 2017, 3, 254-267. [CrossRef]

8. Chan, Y.; Chong, M.; Law, C. Start-up, steady state performance and kinetic evaluation of a thermophilic integrated anaerobicaerobic bioreactor (IAAB). Bioresour. Technol. 2012, 125C, 145-157. [CrossRef] [PubMed]

9. Poh, P.E.; Chong, M. Upflow anaerobic sludge blanket-hollow centered packed bed (UASB-HCPB) reactor for thermophilic palm oil mill effluent (POME) treatment. Biomass Bioenergy 2014, 67, 231-242. [CrossRef]

10. Shafie, N.F.A.; Mansor, U.Q.A.; Yahya, A.; Som, A.M.; Nour, A.H.; Hassan, Z.; Yunus, R.M.A.R.M. The performance study of Ultrasonic-assisted Membrane Anaerobic System (UMAS) for Chemical Oxygen Demand (COD) removal efficiency and methane gas production in Palm Oil Mill Effluent (POME) treatment. In Proceedings of the 4th IET Clean Energy and Technology Conference, Kuala Lampur, Malaysia, 14-15 November 2016; pp. 1-5.

11. Cheng, Y.; Chong, C.; Lam, M.; Leong, W.; Chuah, L.F.; Suzana, Y.; Setiabudi, H.; Tang, Y.; Lim, J.-W. Identification of microbial inhibitions and mitigation strategies towards cleaner bioconversions of Palm Oil Mill Effluent (POME): A review. J. Clean Prod. 2020, 280. [CrossRef]

12. Bala, J.D.; Lalung, J.; Ismail, N. Biodegradation of Palm Oil Mill Effluent (POME) by bacterial. Int. J. Sci. Res. 2014, 4, 2250-3153.

13. Affam, A. Conventional methods and emerging wastewater polishing technologies for palm oil effluent treatment-A review. J. Environ. Manag. 2015, 149, 222-235.

14. Lee, Z.S.; Chin, S.Y.; Lim, J.W.; Witoon, T.; Cheng, C.K. Treatment technologies of Palm Oil Mill Effluent (POME) and olive mill wastewater (OMW): A brief review. Environ. Technol. Innov. 2019, 15, 100377. [CrossRef]

15. Darajeh, N.; Idris, A.; Truong, P.; Aziz, H.; Bakar, R.; Che Man, H. phytoremediation potential of vetiver system technology for improving the quality of palm oil mill effluent. Adv. Mater. Sci. Eng. 2014, 2014. [CrossRef]

16. Karim, A.; Islam, M.A.; Yousuf, A.; Khan, M.M.R.; Faizal, C.K.M. Microbial lipid accumulation through bioremediation of palm oil mill wastewater by bacillus cereus. ACS Sustain. Chem. Eng. 2019, 7, 14500-14508. [CrossRef]

17. Wahi, R.; Luqman Chuah, A.; Mobarekeh, M.; Ngaini, Z.; Yaw, T. Utilization of esterified sago bark fibre waste for removal of oil from Palm Oil Mill Effluent. J. Environ. Chem. Eng. 2016, 5. [CrossRef]

18. Azmi, N.; Yunos, K. Wastewater treatment of palm oil mill effluent (POME) by ultrafiltration membrane separation technique coupled with adsorption treatment as pretreatment. Agric. Agric. Sci. Proc. 2014, 2, 257-264. [CrossRef]

19. Chairunnisak, A.; Arifin, B.; Sofyan, H.; Lubis, M.R. Darmadi Comparative study on the removal of COD from POME by electrocoagulation and electro-Fenton methods: Process optimization. IOP Conf. Ser. Mater. Sci. Eng. 2018, 334, 12026. [CrossRef] 
20. Ahmed, Y.; Yaakob, Z.; Akhtar, P.; Sopian, K. Production of biogas and performance evaluation of existing treatment processes in Palm Oil Mill Effluent (POME). Renew. Sustain. Energy Rev. 2015, 42, 1260-1278. [CrossRef]

21. Iskandar, M.J.; Baharum, A.; Anuar, F.H.; Othaman, R. Palm oil industry in South East Asia and the effluent treatment technologyA review. Environ. Technol. Innov. 2018, 9, 169-185. [CrossRef]

22. Wu, T.Y.; Mohammad, A.W.; Jahim, J.M.; Anuar, N. Pollution control technologies for the treatment of Palm Oil Mill Effluent (POME) through end-of-pipe processes. J. Environ. Manag. 2010, 91, 1467-1490. [CrossRef]

23. Lam, M.K.; Lee, K.T. Renewable and sustainable bioenergies production from Palm Oil Mill Effluent (POME): Win-win strategies toward better environmental protection. Biotechnol. Adv. 2011, 29, 124-141. [CrossRef] [PubMed]

24. Bello, M.; Nourouzi, M.; Luqman Chuah, A.; Choong, T.; Koay, Y.; Keshani, S. POME is treated for removal of color from biologically treated POME in fixed bed column: Applying wavelet neural network (WNN). J. Hazard. Mater. 2013, 262C, 106-113. [CrossRef]

25. Santosa, S. Palm oil boom in Indonesia: From plantation to downstream products and biodiesel. Clean Soil Air Water 2008, 36, 453-465. [CrossRef]

26. Ng, W.J.; Goh, A.C.C.; Tay, J.H. Palm Oil Mill Effluent (POME) treatment-An assessment of coagulants used to aid liquid-solid separation. Biol. Wastes 1987, 21, 237-248. [CrossRef]

27. Kushairi, A.; Ong-Abdullah, M.; Nambiappan, B.; Hishamuddin, E.; Izuddin, Z.; Ghazali, R.; Subramaniam, V.; Sundram, S.; Ghulam Kadir, A.P. Oil palm economic performance in Malaysia and R\&D progress in 2018. J. Oil Palm Res. 2019, 31, 165-194.

28. Loh, S.K.; LAI, M.E.; Ngatiman, M.; Weng Soon, L.; Choo, Y.; Zhang, Z.; Salimon, J. Zero discharge treatment technology of palm oil mill effluent. J. Oil Palm Res. 2013, 25, 273-281.

29. Hayawin, Z.; Astimar, A.A.; Idris, J.; Jalani, N.F.; Mamat, R.; Ibrahim, M.; Hassan, M.; Abd-Aziz, S. Reduction of POME final discharge residual using activated bioadsorbent from oil palm kernel shell. J. Clean. Prod. 2018, 182. [CrossRef]

30. Zahrim, A.Y.; Nasimah, A.; Hilal, N. Pollutants analysis during conventional Palm Oil Mill Effluent (POME) ponding system and decolourisation of anaerobically treated POME via calcium lactate-polyacrylamide. J. Water Process. Eng. 2014, 4, 159-165. [CrossRef]

31. Chin, M.; Poh, P.E.; Tey, B.T.; Chan, E.; Chin, K.L. Biogas from Palm Oil Mill Effluent (POME): Opportunities and challenges from Malaysia's perspective. Renew. Sustain. Energ. Rev. 2013, 26, 717-726. [CrossRef]

32. Laws of Malaysia. Environment Quality Act 1974-Environment Quality; International Law Book Services: Petaling Jaya, Malaysia, 2020; ISBN 978-967-89-2846-5.

33. Yaser, A.; Mansa, R.; Menaka, S.; Su, S.Y.; Melvin, F.; Chan, E.S. Decolorisation of anaerobic palm oil mill effluent via activated sludge-granular activated carbon. World Appl. Sci. J. 2009, 5, 126-129.

34. Tamrin, K.; Yaser, A. Determination of optimum polymeric coagulant in palm oil mill effluent coagulation using multiple-objective optimisation on the basis of ratio analysis (MOORA). Environ. Sci. Pollut. Res. 2017, 24. [CrossRef]

35. Hosseini, S.E.; Wahid, M. Pollutant in palm oil production process. J. Air Waste Manag. Assoc. 2013, 65. [CrossRef]

36. Nurliyana, M.; H'ng, P.S.; Rasmina, H.; Umi Kalsom, M.S.; Chin, K.L.; Lee, S.H.; Lum, W.C.; Khoo, G.D. Effect of C/N ratio in methane productivity and biodegradability during facultative co-digestion of palm oil mill effluent and empty fruit bunch. Ind. Crops Prod. 2015, 76, 409-415. [CrossRef]

37. Yacob, S.; Hassan, M.; Shirai, Y.; Wakisaka, M.; Subash, S. Baseline study of methane emission from open digesting tanks of palm oil mill effluent treatment. Chemosphere 2005, 59, 1575-1581. [CrossRef]

38. Hasanudin, U.; Sugiharto, R.; Haryanto, A.; Setiadi, T.; Fujie, K. Palm oil mill effluent treatment and utilization to ensure the sustainability of palm oil industries. Water Sci. Technol. 2015, 72. [CrossRef] [PubMed]

39. Chan, Y.J.; Hue, F.S.; Chong, M.F.; Ng, D.K.S.; Lim, D.L.K. Pre-commercialized integrated anaerobic-aerobic bioreactor (IAAB) for Palm Oil Mill Effluent (POME) treatment and biogas generation. J. Oil Palm Environ. Health 2020, 11, 57-66.

40. Poh, P.E.; Chong, M. Biomethanation of Palm Oil Mill Effluent (POME) with a thermophilic mixed culture cultivated using POME as a substrate. Chem. Eng. J. 2010, 164, 146-154. [CrossRef]

41. Md. Som, A.; Yahya, A.; Shafie, N.F.A.; Mansor, U.Q.A.; Nour, N.H.; Yunus, R.; Hassan, Z. Performance of Ultrasonic-assisted Membrane Anaerobic System (UMAS) for Membrane Fouling Control in Palm Oil Mill Effluent (POME) treatment. Adv. Sci. Lett. 2017, 23, 3903-3906.

42. Chou, K.W.; Tan, S.; Morad, N.; Teng, T.T.; Kadir, M.; Ismail, N. Aerobic post-treatment of different anaerobically digested Palm Oil Mill Effluent (POME). Int. J. Environ. Sci. Dev. 2016, 7, 511-515. [CrossRef]

43. Sa'at, S.K.M.; Zaman, N.Q. Phytoremediation potential of palm oil mill effluent by constructed wetland treatment. Eng. Herit. J. 2017, 1, 49-54. [CrossRef]

44. Purwanti, P.; Elystia, S.; Sasmita, A. Treatment of Palm Oil Mill Effluent through Phytoremediation Using Typha Latifolia. Ph.D. Thesis, Riau University, Riau, Indonesia, 2014.

45. Zulfahmi, I.; Kandi, R.N.; Huslina, F.; Rahmawati, L.; Muliari, M.; Sumon, K.A.; Rahman, M.M. Phytoremediation of Palm Oil Mill Effluent (POME) using water spinach (Ipomoea aquatic Forsk). Environ. Technol. Innov. 2021, 21, 101260. [CrossRef]

46. Baihaqi, B.; Rahmat, M.; Zulfahmi, I.; Muslich, H. Bioremediation of Palm Oil Mill Effluent (POME) using Spirogyra sp. J. Biot. 2017, 5, 125-134. 
47. Chen, J.-C.; Wang, K.-S.; Chen, H.; Lu, C.-Y.; Huang, L.-C.; Li, H.-C.; Peng, T.-H.; Chang, S.-H. Phytoremediation of Cr(III) by Ipomonea aquatica (water spinach) from water in the presence of EDTA and chloride: Effects of Cr speciation. Bioresour. Technol. 2010, 101, 3033-3039. [CrossRef] [PubMed]

48. Bedabati Chanu, L.; Gupta, A. Phytoremediation of lead using Ipomoea aquatica Forsk. in hydroponic solution. Chemosphere 2016, 156, 407-411. [CrossRef]

49. Chandanshive, V.V.; Kadam, S.K.; Khandare, R.V.; Kurade, M.B.; Jeon, B.-H.; Jadhav, J.P.; Govindwar, S.P. In situ phytoremediation of dyes from textile wastewater using garden ornamental plants, effect on soil quality and plant growth. Chemosphere 2018, 210, 968-976. [CrossRef]

50. Effendi, H.; Margaretha, J.; Krisanti, M. Reducing ammonia and chromium concentration in batik wastewater by vetiver (Chrysopogon zizanioides L.) grown in floating wetland. Appl. Ecol. Environ. Res. 2018, 16, 2947-2956. [CrossRef]

51. Hamzah, M.F.; Alimon, H.; Yusof, N. Phytoremediation of palm oil mill final discharge wastewater using aquatic macrophytes leersia oryzoides, pistia stratoites and ludwigia peploides. J. Sci. Math. Lett. 2019, 4, 23-31.

52. Redzwan, O. The utilization of water hyacinth (Eichorniacrassipes) as aquatic macrophage treatment systems (AMATS) in phytoremediation for Palm Oil Mill Effluent (POME). Int. J. Sci. Basic Appl. Res. 2014, 13, 31-47.

53. Hazman, N.; Nazlina Haiza, M.Y.; Takriff, M.; Abu Hasan, H.; Kamarudin, K.; Hakimi, N. Integrated palm oil mill effluent treatment and $\mathrm{CO}_{2}$ sequestration by microalgae. Sains Malays. 2018, 47, 1455-1464. [CrossRef]

54. Hariz, H.B.; Takriff, M.S.; Mohd Yasin, N.H.; Ba-Abbad, M.M.; Mohd Hakimi, N.I.N. Potential of the microalgae-based integrated wastewater treatment and $\mathrm{CO}_{2}$ fixation system to treat Palm Oil Mill Effluent (POME) by indigenous microalgae; Scenedesmus sp. and Chlorella sp. J. Water Process Eng. 2019, 32, 100907. [CrossRef]

55. Zubairi, T.D.S.; Mantalaris, A.; Bismarck, A.; Aizad, S. Polyhydroxyalkanoates (PHAs) for tissue engineering applications: Biotransformation of Palm Oil Mill Effluent (POME) to value-added polymers. J. Technol. 2016, 78, 13-29. [CrossRef]

56. Nwuche, C.; Aoyagi, H.; Ogbonna, J. Citric acid production from cellulase-digested palm oil mill effluent. Asian J. Biotechnol. 2013, 5, 51-60. [CrossRef]

57. Wakil, S.; Fasiku, S.; Adelabu, B.; Onilude, A. Production of bioethanol from spontaneous fermentation of Palm Oil Mill Effluent (POME). Researcher 2013, 5, 28-35.

58. Islam, A.; Rahman, M.; Yousuf, A.; Cheng, C.K.; Woon, C. Performance of Klebsiella oxytoca to generate electricity from POME in microbial fuel cell. In MATEC Web of Conferences; EDP Sciences: Les Ulis, France, 2016; Volume 38.

59. Baranitharan, E.; Khan, M.R.; Prasad, D.M.R.; Bin Salihon, J. Bioelectricity generation from Palm Oil Mill Effluent in microbial fuel cell using polacrylonitrile carbon felt as electrode. Water Air Soil Pollut. 2013, 224. [CrossRef]

60. Cheng, J.; Zhu, X.; Ni, J.; Borthwick, A. Palm oil mill effluent treatment using a two-stage microbial fuel cells system integrated with immobilized biological aerated filters. Bioresour. Technol. 2010, 101, 2729-2734. [CrossRef]

61. Wang, J.; Mahmood, Q.; Qiu, J.; Li, Y.-S.; Chang, Y.-S.; Li, X.-D. Anaerobic treatment of Palm Oil Mill Effluent in pilot-scale anaerobic EGSB reactor. BioMed. Res. Int. 2015, 2015, 398028. [CrossRef]

62. Damayanti, S.; Bayonita, S.; Wiratni, W.; Sarto, S.; Mustika, I.; Purnomo, C. The study of immobilized media and ni ion addition effects on COD removal of POME using anaerobic filter reactor. Waste Biomass Valorization 2020, 11. [CrossRef]

63. Bala, J.; Lalung, J.; Al-Gheethi, A.; Kaizar, H.; Ismail, N. Reduction of organic load and biodegradation of palm oil mill effluent by aerobic indigenous mixed microbial consortium isolated from Palm Oil Mill Effluent (POME). Water Conserv. Sci. Eng. 2018, 3. [CrossRef]

64. Bala, J.; Lalung, J.; Ismail, N. Studies on the reduction of organic load from palm oil mill effluent (POME) by bacterial strains. Int. J. Recycl. Org. Waste Agric. 2014, 4. [CrossRef]

65. Khadaroo, S.N.B.A.; Grassia, P.; Gouwanda, D.; Poh, P.E. The impact of thermal pretreatment on various solid-liquid ratios of Palm Oil Mill Effluent (POME) for enhanced thermophilic anaerobic digestion performance. J. Clean. Prod. 2020, $261,121159$. [CrossRef]

66. Lanka, S.; Muralidhar, P. Reduction of organic load from palm oil mill effluent (POME) using selected fungal strains isolated from POME dump sites. Afr. J. Biotechnol. 2018, 17, 1138-1145. [CrossRef]

67. Al-Mamun, A.; Idris, A. Treatment of POME by pilot plant anaerobic fluidised bed reactor. IIUM Eng. J. 2010, 9. [CrossRef]

68. Yap, C.C.; Loh, S.K.; Chan, Y.J.; Supramaniam, C.V.; Chong, M.F.; Soh, A.C.; Lim, L.K.; Loo, L.S. Synergistic effect of anaerobic co-digestion of palm oil mill effluent (POME) with Moringa oleifera extract. Biomass Bioenergy 2021, 144, 105885. [CrossRef]

69. Wun, W.; Chua, G.K.; Chin, S. Effect of palm oil mill effluent pome treatment by activated sludge. J. Clean WAS 2017, 1, 6-9. [CrossRef]

70. Tabassum, S. An integrated method for Palm Oil Mill Effluent (POME) treatment for achieving zero liquid discharge-A pilot study. J. Clean. Prod. 2015, 95, 148-155. [CrossRef]

71. Kamaruddin, M.; Ismail, N.; Kuen, T.H.; Alrozi, R. Sustainable treatment of Palm Oil Mill Effluent (POME) by using pectin and chitosan in jar test protocol-Sequential comparison. Int. J. Integr. Eng. 2018, 10, 163-169. [CrossRef]

72. Krishnan, S.; Singh, L.; Mishra, P.; Nasrullah, M.; Sakinah, M.; Thakur, S.; Siddique, N.I.; Wahid, Z.A. Comparison of process stability in methane generation from palm oil mill effluent using dairy manure as inoculum. Environ. Technol. Innov. 2017, 8, 360-365. [CrossRef] 
73. Abu Bakar, S.N.H.; Abu Hasan, H.; Mohammad, A.W.; Abdullah, S.R.S.; Ngteni, R.; Yusof, K.M.M. Performance of a laboratoryscale moving bed biofilm reactor (MBBR) and its microbial diversity in Palm Oil Mill Effluent (POME) treatment. Process. Saf. Environ. Prot. 2020, 142, 325-335. [CrossRef]

74. Mohammed, R. Decolorisation of biologically treated Palm Oil Mill Effluent (POME) using adsorption technique. Int. Ref. J. Eng. Sci. 2013, 2, 1-11.

75. Liew, R.K.; Azwar, E.; Yek, P.N.Y.; Lim, X.Y.; Cheng, C.K.; Ng, J.-H.; Jusoh, A.; Lam, W.H.; Ibrahim, M.D.; Ma, N.L.; et al. Microwave pyrolysis with $\mathrm{KOH} / \mathrm{NaOH}$ mixture activation: A new approach to produce micro-mesoporous activated carbon for textile dye adsorption. Bioresour. Technol. 2018, 266, 1-10. [CrossRef]

76. Rugayah, A.F.; Astimar, A.A.; Ngadi, N. Preparation and characterisation of activated carbon from palm kernel shell by physical activation with steam. J. Oil Palm Res. 2014, 26, 251-264.

77. Lam, S.S.; Liew, R.K.; Cheng, C.K.; Rasit, N.; Ooi, C.K.; Ma, N.L.; Ng, J.-H.; Lam, W.H.; Chong, C.T.; Chase, H. Pyrolysis production of fruit peel biochar for potential use in treatment of palm oil mill effluent. J. Environ. Manag. 2018, 213, 400-408. [CrossRef]

78. Othman, M.; Hassan, M.; Shirai, Y.; Baharuddin, A.; Ali, A.; Idris, J. Treatment of effluents from palm oil mill process to achieve river water quality for reuse as recycled water in a zero emission system. J. Clean. Prod. 2014, 67, 58-61. [CrossRef]

79. Abd Wafti, N.S.; Nang, H.; Loh, S.K.; Aziz, A.A.; Rahman, Z.A.; May, C.Y. Activated carbon from oil palm biomass as potential adsorbent for palm oil mill effluent treatment. J. Oil Palm Res. 2017, 29, 278-290. [CrossRef]

80. Deshon, S.; Tan, I.A.W.; Lim, L.L.P. Palm oil mill effluent treatment using coconut shell-based activated carbon: Adsorption equilibrium and isotherm. MATEC Web Conf. 2017, 87, 3009. [CrossRef]

81. Yong Yin, S.; Tan, I.A.W.; Abdullah, M. Adsorption of colour, TSS and COD from Palm Oil Mill Effluent (POME) using acid-washed coconut shell activated carbon: Kinetic and mechanism studies. MATEC Web Conf. 2017, 87, 3010. [CrossRef]

82. Ibrahim, I.; Hassan, M.A.; Abd-Aziz, S.; Shirai, Y.; Andou, Y.; Othman, M.R.; Ali, A.A.M.; Zakaria, M.R. Reduction of residual pollutants from biologically treated palm oil mill effluent final discharge by steam activated bioadsorbent from oil palm biomass. J. Clean. Prod. 2017, 141, 122-127. [CrossRef]

83. Kutty, S.R.M.; Ngatenah, S.; Johan, N.; Amat, K. Removal of Zn(II), Cu(II), chemical oxygen demand (COD) and colour from anaerobically treated Palm Oil Mill Effluent (POME) using Microwave Incinerated Rice Husk ash (MIRHA). In Proceedings of the 2011 International Conference on Environment and Industrial Innovation, Kuala Lampur, Malaysia, 4-5 June 2011.

84. Pandia, S.; Hutagalung, A.; Siahaan, A. Utilization of cocoa peel as biosorbent for oil and color removal in Palm Oil Mill Effluent (POME). IOP Conf. Ser. Mater. Sci. Eng. 2018, 300, 12066. [CrossRef]

85. Wang, J.; Zheng, Y.; Wang, A. Effect of kapok fiber treated with various solvents on oil absorbency. Ind. Crops Prod. 2012, 40, 178-184. [CrossRef]

86. Amat, N.; Tan, Y.I.H.; Lau, W.J.; Lai, G.S.; Chi Siang, O.; Mohd Mokhtar, N.; Sani, N.; Ismail, A.; Goh, P.; Chong, K.; et al. Tackling colour issue of anaerobically-treated Palm Oil Mill Effluent using membrane technology. J. Water Process Eng. 2015, 8, 221-226. [CrossRef]

87. Mohd Asharuddin, S.; Othman, N.; Zin, N.; Tajarudin, H. Removal of total suspended solid by natural coagulant derived from cassava peel waste. J. Phys. Conf. Ser. 2018, 995, 12040. [CrossRef]

88. Malakahmad, A.; Sim, Y. Application of response surface methodology to optimize coagulation-flocculation treatment of anaerobically digested Palm Oil Mill Effluent using alum. Desalin. Water Treat. 2013, 51. [CrossRef]

89. Ullah, A.; Rathnasiri, P.G. Optimization of adsorption-coagulation process for treatment of Palm Oil Mill Effluent (POME) using alternative coagulant. In Proceedings of the International Research Symposium on Engineering Advancements, Malabe, Sri Lanka, 25 April 2015; pp. 68-71.

90. Zinatizadeh, A.A.; Ibrahim, S.; Aghamohammadi, N.; Mohamed, A.; Zangeneh, H.; Mohammadi, P. Polyacrylamide induced coagulation process removing suspended solids from palm oil mill effluent. Sep. Sci. Technol. 2016, 52. [CrossRef]

91. Sayuti, S.C.; Mohd Azoddein, A.A. Treatment of Palm Oil Mill Effluent (POME) by using electrocoagulation as an alternative method. Malays. J. Anal. Sci. 2015, 19, 663-668.

92. Bashir, M.; Han, T.; Lim, J.-W.; Ng, C.; Abu Amr, S. Polishing of treated Palm Oil Mill Effluent (POME) from ponding system by electrocoagulation process. Water Sci. Technol. 2016, 73. [CrossRef]

93. Ibrahim, S.; Aris, N.S.M.; Ariffin, B.; Hawari, Y.; Megat Hanafiah, M.A.K. Application of electrocoagulation process for decolourisation of Palm Oil Mill Effluent (POME). Nat. Environ. Pollut. Technol. 2018, 17, 1267-1271.

94. Gamaralalage, D.; Sawai, O.; Nunoura, T. Degradation behavior of palm oil mill effluent in Fenton oxidation. J. Hazard. Mater. 2019, 364, 791-799. [CrossRef] [PubMed]

95. Kanakaraju, D.; Ahmad, N.L.B.; Sedik, N.B.M.; Long, S.G.H.; Guan, T.M.; Chin, L.Y. Performance of solar photocatalysis and photo-fenton degradation of palm oil mill effluent. Malays. J. Anal. Sci. 2017, 21, 996-1007. [CrossRef]

96. Sani, S.; Dashti, A.F.; Adnan, R. Applications of Fenton oxidation processes for decontamination of Palm Oil Mill Effluent: A review. Arab. J. Chem. 2020, 13, 7302-7323. [CrossRef]

97. Alhaji, M.H.; Sanaullah, K.; Salleh, S.F.; Baini, R.; Lim, S.F.; Rigit, A.R.H.; Said, K.A.M.; Khan, A. Photo-oxidation of pre-treated palm oil mill Effluent using cylindrical column immobilized photoreactor. Process. Saf. Environ. Prot. 2018, 117, 180-189. [CrossRef] 
98. Fujihira, T.; Seo, S.; Yamaguchi, T.; Hatamoto, M.; Tanikawa, D. High-rate anaerobic treatment system for solid/lipid-rich wastewater using anaerobic baffled reactor with scum recovery. Bioresour. Technol. 2018, 263. [CrossRef]

99. Jegatheesan, V.; Pramanik, B.K.; Chen, J.; Navaratna, D.; Chang, C.-Y.; Shu, L. Treatment of textile wastewater with membrane bioreactor: A critical review. Bioresour. Technol. 2016, 204, 202-212. [CrossRef]

100. Said, M.; Ahmad, A.; Mohammad, A.W.; Nor, M.T.M.; Sheikh Abdullah, S.R. Blocking mechanism of PES membrane during ultrafiltration of POME. J. Ind. Eng. Chem. 2015, 21, 182-188. [CrossRef]

101. Keeley, J.; Smith, A.D.; Judd, S.J.; Jarvis, P. Reuse of recovered coagulants in water treatment: An investigation on the effect coagulant purity has on treatment performance. Sep. Purif. Technol. 2014, 131, 69-78. [CrossRef]

102. Agustin, M. Electrocoagulation of Palm Oil Mill Effluent. Int. J. Environ. Res. Public Health 2008, 5, 177-180. [CrossRef]

103. Saeed, M.; Khairun Azizi, A.; Isa, M.H.; Henry Ezechi, E. Treatment of POME using Fenton oxidation process: Removal efficiency, optimization, and acidity condition. Desalin. Water Treat. 2016, 57, 1-10. [CrossRef]

104. Kongnoo, A.; Suksaroj, T.; Intharapat, P.; Promtong, T.; Suksaroj, C. Decolorization and organic removal from Palm Oil Mill Effluent by fenton's process. Environ. Eng. Sci. 2012, 29, 855-859. [CrossRef]

105. Vajnhandl, S.; Marechal, A. Ultrasound in textile dyeing and the decolouration/mineralization of textile dyes. Dye. Pigment. 2005, 65, 89-101. [CrossRef]

106. Dewil, R.; Baeyens, J.; Goutvrind, R. The use of ultrasonics in the treatment of waste activated sludge. Chin. J. Chem. Eng. 2006, 14, 105-113. [CrossRef]

107. Chakinala, A.G.; Gogate, P.R.; Burgess, A.E.; Bremner, D.H. Industrial wastewater treatment using hydrodynamic cavitation and heterogeneous advanced Fenton processing. Chem. Eng. J. 2009, 152, 498-502. [CrossRef]

108. Manickam, S.; Parthasarathy, S.; Alzorqi, I.; Ng, E.H.; Tiong, T.J.; Gomes, R.L.; Ali, A. Role of $\mathrm{H}_{2} \mathrm{O}_{2}$ in the fluctuating patterns of COD (chemical oxygen demand) during the treatment of Palm Oil Mill Effluent (POME) using pilot scale triple frequency ultrasound cavitation reactor. Ultrason. Sonochem. 2014, 21, 1519-1526. [CrossRef]

109. Zheng, X.; Shen, Z.-P.; Shi, L.; Cheng, R.; Yuan, D.-H. Photocatalytic membrane reactors (PMRs) in water treatment: Configurations and influencing factors. Catalysts 2017, 7, 224. [CrossRef]

110. Cheng, C.K.; Deraman, M.R.; Ng, K.H.; Khan, M.R. Preparation of titania doped argentum photocatalyst and its photoactivity towards palm oil mill effluent degradation. J. Clean. Prod. 2016, 112, 1128-1135. [CrossRef]

111. Ng, K.; Cheng, C.K. A novel photomineralization of $\mathrm{POME}$ over UV-responsive $\mathrm{TiO}_{2}$ photocatalyst: Kinetics of POME degradation and gaseous product formations. RSC Adv. 2015, 5, 53100-53110. [CrossRef]

112. Ng, K.; Deraman, M.; Ang, C.; Chong, S.; Kong, Z.; Khan, M.; Cheng, C. Phototreatment of Palm Oil Mill Effluent (POME) over $\mathrm{Cu} / \mathrm{TiO}_{2}$ photocatalyst. Bull. Chem. React. Eng. Catal. 2014, 9. [CrossRef]

113. Li, D.; Zheng, H.; Wang, Q.; Wang, X.; Jiang, W.; Zhang, Z.; Yang, Y. A novel double-cylindrical-shell photoreactor immobilized with monolayer $\mathrm{TiO}_{2}$-coated silica gel beads for photocatalytic degradation of Rhodamine B and Methyl Orange in aqueous solution. Sep. Purif. Technol. 2014, 123, 130-138. [CrossRef]

114. Khatamian, M.; Hashemian, S.; Yavari, A.; Saket Osgouei, M. Preparation of metal ion $\left(\mathrm{Fe}^{3+}\right.$ and $\left.\mathrm{Ni}^{2+}\right)$ doped $\mathrm{TiO}_{2}$ nanoparticles supported on ZSM-5 zeolite and investigation of its photocatalytic activity. Mater. Sci. Eng. B 2012, 177, 1623-1627. [CrossRef]

115. Cheng, Y.W.; Lee, Z.S.; Chong, C.C.; Khan, M.R.; Cheng, C.K.; Ng, K.H.; Hossain, S.S. Hydrogen-rich syngas production via steam reforming of Palm Oil Mill Effluent (POME)—A thermodynamics analysis. Int. J. Hydrogen Energy 2019, 44, 20711-20724. [CrossRef]

116. Ng, K.H.; Cheng, Y.W.; Lee, Z.S.; Khan, M.R.; Lam, S.S.; Cheng, C.K. Experimental evaluation and empirical modelling of palm oil mill effluent steam reforming. Int. J. Hydrogen Energy 2018, 43, 15784-15793. [CrossRef]

117. $\mathrm{Ng}$, K.H.; Cheng, Y.W.; Lee, Z.S.; Cheng, C.K. A study into syngas production from catalytic steam reforming of palm oil mill effluent (POME): A new treatment approach. Int. J. Hydrogen Energy 2019, 44, 20900-20913. [CrossRef]

118. Sivasangar, S.; Zainal, Z.; Salmiaton, A.; Taufiq-Yap, Y.H. Supercritical water gasification of empty fruit bunches from oil palm for hydrogen production. Fuel 2015, 143, 563-569. [CrossRef]

119. Parthasarathy, S.; Mohammed, R.R.; Fong, C.M.; Gomes, R.L.; Manickam, S. A novel hybrid approach of activated carbon and ultrasound cavitation for the intensification of Palm Oil Mill Effluent (POME) polishing. J. Clean. Prod. 2016, 112, 1218-1226. [CrossRef]

120. Neoh, C.; Yahya, A.; Adnan, R.; Abdul Majid, Z.; Ibrahim, Z. Optimization of decolorization of Palm Oil Mill Effluent (POME) by growing cultures of Aspergillus fumigatus using response surface methodology. Environ. Sci. Pollut. Res. Int. 2012, 20. [CrossRef]

121. Mohammed, R.; Ketabchi, M.R.; Mckay, G. Combined magnetic field and adsorption process for treatment of biologically treated palm oil mill effluent (POME). Chem. Eng. J. 2014, 243, 31-42. [CrossRef]

122. Surup, G.R.; Leahy, J.J.; Timko, M.T.; Trubetskaya, A. Hydrothermal carbonization of olive wastes to produce renewable, binder-free pellets for use as metallurgical reducing agents. Renew. Energy 2020, 155, 347-357. [CrossRef]

123. Trubetskaya, A.; Leahy, J.J.; Yazhenskikh, E.; Muller, M.; Layden, P.; Johnson, R.; Stahl, K.; Monaghan, R.F.D. Characterization of woodstove briquettes from torrefied biomass and coal. Energy 2019, 171, 853-865. [CrossRef]

124. Hassan, S.; Kee, L.S.; Al-Kayiem, H.H. Experimental study of palm oil mill effluent and oil palm frond wastes mixtures as an alternative biomass fuel. J. Eng. Sci. Technol. 2013, 8, 703-712. 